\title{
Artificial primary marine aerosol production: a laboratory study with varying water temperature, salinity, and succinic acid concentration
}

\author{
J. Zábori ${ }^{1}$, M. Matisāns ${ }^{1}$, R. Krejci ${ }^{1,2}$, E. D. Nilsson ${ }^{1}$, and J. Ström ${ }^{1}$ \\ ${ }^{1}$ Department of Applied Environmental Science, Stockholm University, 11418 Stockholm, Sweden \\ ${ }^{2}$ Department of Physics, University of Helsinki, 00014 Helsinki, Finland
}

Correspondence to: J. Zábori (julia.zabori@itm.su.se)

Received: 29 June 2012 - Published in Atmos. Chem. Phys. Discuss.: 2 August 2012

Revised: 9 November 2012 - Accepted: 12 November 2012 - Published: 16 November 2012

\begin{abstract}
Primary marine aerosols are an important component of the climate system, especially in the remote marine environment. With diminishing sea-ice cover, better understanding of the role of sea spray aerosol on climate in the polar regions is required. As for Arctic Ocean water, laboratory experiments with $\mathrm{NaCl}$ water confirm that a few degrees change in the water temperature $\left(T_{\mathrm{w}}\right)$ gives a large change in the number of primary particles. Small particles with a dry diameter between $0.01 \mu \mathrm{m}$ and $0.25 \mu \mathrm{m}$ dominate the aerosol number density, but their relative dominance decreases with increasing water temperature from $0{ }^{\circ} \mathrm{C}$ where they represent $85-90 \%$ of the total aerosol number to $10^{\circ} \mathrm{C}$, where they represent $60-70 \%$ of the total aerosol number. This effect is most likely related to a change in physical properties and not to modification of sea water chemistry. A change of salinity between $15 \mathrm{~g} \mathrm{~kg}^{-1}$ and $35 \mathrm{~g} \mathrm{~kg}^{-1}$ did not influence the shape of a particle number size distribution. Although the magnitude of the size distribution for a water temperature change between $0{ }^{\circ} \mathrm{C}$ and $16^{\circ} \mathrm{C}$ changed, the shape did not. An experiment where succinic acid was added to a $\mathrm{NaCl}$ water solution showed, that the number concentration of particles with $0.010 \mu \mathrm{m}<D_{\mathrm{p}}<4.5 \mu \mathrm{m}$ decreased on average by $10 \%$ when the succinic acid concentration in $\mathrm{NaCl}$ water at a water temperature of $0{ }^{\circ} \mathrm{C}$ was increased from $0 \mu \mathrm{mol} \mathrm{L}-1$ to $94 \mu \mathrm{mol} \mathrm{L}^{-1}$. A shift to larger sizes in the particle number size distribution is observed from pure $\mathrm{NaCl}$ water to Arctic Ocean water. This is likely a consequence of organics and different inorganic salts present in Arctic Ocean water in addition to the $\mathrm{NaCl}$.
\end{abstract}

\section{Introduction}

Sea salt aerosols released by bubble bursting from the ocean into the atmosphere are the largest aerosol source globally with respect to aerosol mass (Textor et al., 2006) and play an important role for the radiative balance in remote marine areas. These aerosols influence the global top-ofthe-atmosphere clear-sky radiative forcing (Haywood et al., 1999; Ma et al., 2008; Grini et al., 2002; Zhao et al., 2008) and are understood as an important source for cloud condensation nuclei (Pierce and Adams, 2006). Both, the direct and indirect effect of sea salt particles represent a negative radiative forcing. Due to sea ice retreat, as a consequence of global warming, the conditions and magnitude of Arctic primary marine aerosol source may rapidly change in the near future. During the last decades an accelerated decrease in sea ice extent in the Arctic Ocean has been observed (Comiso et al., 2008), resulting in an increase of the Arctic primary marine aerosol source area and altered energy and particle fluxes. Both the physical and chemical properties of the Arctic Ocean water are changing. Sea surface temperature has increased over the past few decades (Steele et al., 2008). Concurrently, salinity in surface waters is expected to decrease locally, given an expected enhancement in the negative mass balance of glaciers (Nuth et al., 2010). Additionally to the fresh water inflow due to the melt of glaciers, it was indicated that salinities in the Arctic Ocean were lowered by changes in the interplay between wind fields, melting sea ice and river runoff (Giles et al., 2012; MacDonald et al., 2002). Salinities lower than $30 \%$ are frequently observed during summertime

Published by Copernicus Publications on behalf of the European Geosciences Union. 
in the surface waters of the Arctic Ocean (Raskoff et al., 2010; EWG, 1998; Giles et al., 2012; MacDonald et al., 2002; Stepanova et al., 2007). As a consequence of these altered environmental conditions the fauna and flora in the Arctic Ocean is also expected to change along with the sea water organic content (Wassmann and Reigstad, 2011; Tremblay et al., 2011).

The detailed process of primary marine aerosol emission as a result of a bubble bursting is complex. Even the simple parameter of water temperature influences the physical properties of water in various ways; an increase in water temperature lowers the surface tension, viscosity and the solubility of gases in the water, and increases the molecular diffusivity (Thorpe et al., 1992). All these parameters alter the air bubble behavior in the water, such as the time taken for bubble bursting, the bubble rise speed, and the exchange rate between the two phases in the water. Several parameterizations to describe marine aerosol emissions have been developed over the last few decades (Monahan et al., 1986; Gong, 2003; Mårtensson et al., 2003; Clarke et al., 2006). All parameterizations include the whitecap coverage (the result of a bubble plume reaching the surface), which has been shown to be a strong function of wind speed.

In this study we focus on the effect on $\mathrm{NaCl}$ particle generation from bubble bursting caused by changes in water temperature near freezing conditions, motivated by observations of Arctic Ocean water (Zábori et al., 2012) which revealed a strong temperature dependence of particle emissions near freezing temperatures. The impact of salinity and a surfaceactive compound (succinic acid) on the water temperature dependent trend of particle number concentration is studied by varying $\mathrm{NaCl}$ and succinic acid concentrations on a wider range than expected in real conditions. This is to test how robust and influential links between salinity, surfactant concentrations and PMA emissions are. Through these experiments we test the hypothesis indicated in Zábori et al. (2012) that changes in PMA emission from water with temperatures close to the freezing point are likely controlled by sea water physical properties without a significant impact of organic compounds.

\section{Methods}

\subsection{Instrumentation}

During the laboratory experiments we used an identical instrumental setup to that used during laboratory experiments with real Arctic sea water in 2010 (Zábori et al., 2012). Instruments providing information on total particle number concentrations, size distributions and parameters describing the state of the sampled air (air temperature and relative humidity) were contained in a compact rack. The sampled air was fed to the instruments through a $2 \mathrm{~m}$ long $1 / 4^{\prime \prime}$ diameter stainless steel tube. Due to the geometry of the aerosol sampling line and associated internal losses, the effective upper size limit was estimated to be $5 \mu \mathrm{m}$ (dry diameter, $D_{\mathrm{p}}$ ). Relative humidity in the sampling line was measured by a Hygroclip SC04 (Rotronic) hygrometer and this was used to monitor whether hygroscopic growth could have impacted on particle number concentrations. The mean relative humidity $\left(\mathrm{RH}_{\text {mean }}\right)$ during all experiments was lower than $30 \%$, except for one case, where it was $43 \%$. Particle sizes measured at a mean relative humidity smaller than $30 \%$ are considered to have dry diameters. This is not the case for the particle sizes with a mean relative humidity of $43 \%$. In the following text this will clearly be pointed out.

Total aerosol number concentrations for $D_{\mathrm{p}}$ larger than $0.01 \mu \mathrm{m}$ were measured at $1 \mathrm{~Hz}$ by a TSI 3010 Condensation Particle Counter (CPC) and particles $0.25 \mu \mathrm{m}<D_{\mathrm{p}}<32 \mu \mathrm{m}$ were determined in 31 different size classes using a GRIMM 1.109 Optical Particle Counter (OPC) once every $6 \mathrm{~s}$. Size distributions of smaller particles were measured by a custombuilt Differential Mobility Analyzer connected to a TSI 3010 CPC. This Differential Mobility Particle Sizer (DMPS) system operated in the size range $0.01 \mu \mathrm{m}$ to $0.398 \mu \mathrm{m}$, where particles were divided into 17 size classes. Water temperature $\left(T_{\mathrm{w}}\right)$ and salinity were measured by a Hach HQ40d conductivity and temperature sensor with a precision of $\pm 0.3^{\circ} \mathrm{C}$ for temperature and $\pm 0.1 \mathrm{~g} \mathrm{~kg}^{-1}$ for salinity.

\subsection{Aerosol generation}

Primary marine aerosols are produced by bubble bursting on the water surface. To produce air bubbles in surface water numerous techniques can be applied: Pumping filtered air through a porous media situated in the water (e.g., Mårtensson et al., 2003), producing water waves in a simulation tank which are then allowed to break (e.g., Bowyer et al., 1990), or splashing water on a pre-existing water surface, for example by using a jet of water (e.g., Hultin et al., 2010). Fuentes et al. (2010a) evaluated different methods (except the large simulation tank) with respect to their ability to generate primary marine aerosol by analyzing the bubble spectrum, submicron size distribution, hygroscopicity and cloud condensation nuclei activity. The authors reported that different methods gave very different bubble spectra and as a result different aerosol properties. The use of oceanic water showed that the impinging water jet best simulated the marine primary particle production observed in the ocean and this is also the method employed in this study.

\subsection{Surfactant}

The surfactant chosen for the experiments was succinic acid, since it is a water-soluble organic compound and ubiquitous in different compartments of the environment (Mahiuddin et al., 2008; Hyvärinen et al., 2006). Succinic acid belongs to a group of low molecular weight dicarboxylic acids (DCA), which are amongst others synthesized and metabolized in 
different biochemical processes in sea water (Steinberg and Bada, 1984; Kester and Foster, 1963). Succinic acid is, with concentrations of less than $1 \mu \mathrm{g} \mathrm{L}^{-1}$ one of the lower concentrated DCA in sea water (Tedetti et al., 2006), but can still be considered to represent other DCA, such as oxalic acid, malonic acid and adipic acid. Even that succinic acid is present in the ocean, it cannot be considered to represent the behavior of an average marine biogenic organic. The exudates of marine organisms like phytoplankton and bacteria, are characterized by polymeric structures which eventually may assemble and form microgels (Chin et al., 1998; Passow, 2002). The polymeric structures and microgels are characterized by high molecular weights and therefore next to their difference in chemical properties have a different impact on the physical properties of water compared to succinic acid. Although succinic acid is not representing the impact of average biogenic organics on water properties and consequently on aerosol properties, it is justifiable to use it as a proxy for the experiments carried out in this study.

\subsection{Experimental setup}

About $90 \mathrm{~L}$ of water per experiment was used to fill a stainless steel tank with a capacity of $190 \mathrm{~L}$ in total. The tank was used as a "buffer" tank from which water was pumped with a rate of $2.5 \mathrm{~L} \mathrm{~min}^{-1}$ using an EHEIM centrifugal pump into a carefully sealed polyethylene bottle (Nalgene Labware). A $5 \mathrm{~mm}$ inner diameter stainless steel nozzle in the PET bottle generated a constant water-jet that impinged on a preexisting water surface. A simple overflow system within the PET bottle kept the water level stable and the water volume remained constant at $10 \mathrm{~L}$. The distance between the nozzle exit and the water surface was approximately $16 \mathrm{~cm}$. Water that entered the overflow drain was fed back to the stainless steel tank by gravity. To avoid any contamination by room air, a filtered particle free air stream was pumped at $7 \mathrm{~L} \mathrm{~min}^{-1}$ into the PET bottle. Repeated checks by switching off the water pump were made to ensure the integrity of the system and that particles in the room air did not enter the system. The aerosol sample was taken directly above the water surface in the PET bottle at a distance of about $18 \mathrm{~cm}$ (Fig. 1), with a sampling rate of $6 \mathrm{~L} \mathrm{~min}^{-1}$. Water temperature and salinity were measured in the outflow of the PET bottle into the steel tank.

\subsection{Experiments}

Initially, measurements with clean de-ionized MilliQ water (MQ) were conducted to test the functionality of the experimental setup and to create a baseline case for further experiments with higher salinities. Water was collected from a MQ system (Millipore, MiliQ Plus 185) some days before the start of the experiment and was kept frozen at temperatures of $-20^{\circ} \mathrm{C}$ until the preparation for the experiment began. Before the experiment, the frozen MQ water was left

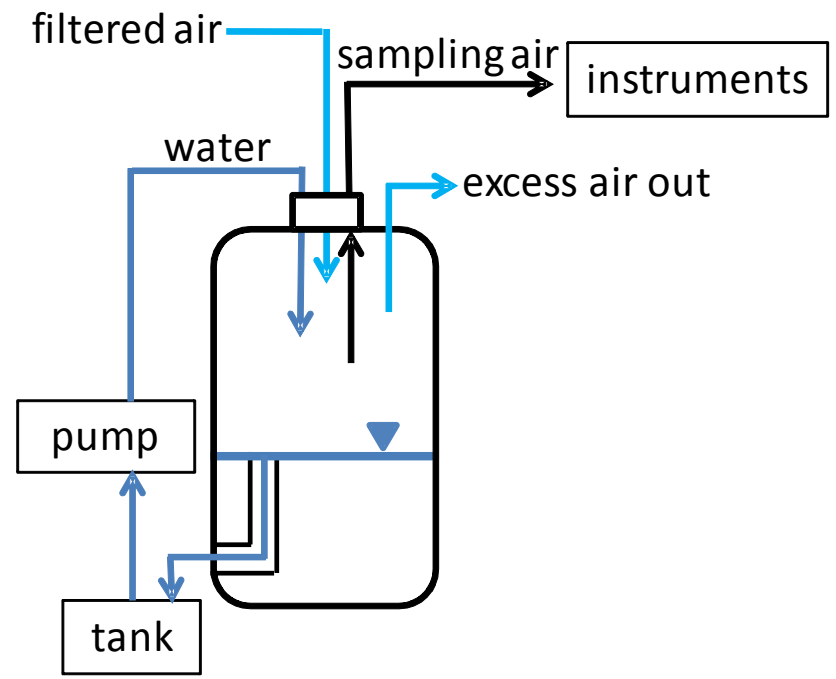

Fig. 1. Schematic picture of bubble bursting experimental setup. The tank was used as a buffer to recirculate the sea water sample trough the PET bottle, where primary marine aerosols were produced by an impinging water jet. Darker blue lines represent water, and the triangle symbol indicates the water surface in the bottle.

to melt until it reached a water temperature of $7.4{ }^{\circ} \mathrm{C}$. During the experiment the MQ water was then cooled down to $1.7^{\circ} \mathrm{C}$ (cooling rate of $1.1^{\circ} \mathrm{Ch}^{-1}$ ) and again left to warm up to $7.4{ }^{\circ} \mathrm{C}$ (warming rate of $0.4^{\circ} \mathrm{Ch}^{-1}$ ). Cooling was facilitated using dry ice, kept in a stainless steel bucket in the buffer tank. By removing the cooling bucket the water temperature increased towards the ambient room temperature. Experiments were conducted for low water temperatures in order to emulate experiments conducted with Arctic Ocean water and to investigate the large sensitivity of particle number concentration expected at low temperatures (Zábori et al., 2012).

A similar experiment was repeated for waters with different salinities and different cooling/warming temperature ranges. To minimise any organic matter contamination, salinities of $18 \mathrm{~g} \mathrm{~kg}^{-1}$ and $35 \mathrm{~g} \mathrm{~kg}^{-1}$ were achieved by adding $\mathrm{NaCl}$ (sodium chloride, puriss.p.a, Sigma-Aldrich) to fresh MQ water in the buffer tank. Once the respective salinity was stable in the outflow of the PET bubble, the experiment started with a cooling sequence, as described above. The experiment using water with a salinity of $18 \mathrm{~g} \mathrm{~kg}^{-1}$ initially had a water temperature of $21.4^{\circ} \mathrm{C}$ and was cooled down to $0.3^{\circ} \mathrm{C}$ (cooling rate of $1.2^{\circ} \mathrm{Ch}^{-1}$ ) before the water was left to warm up to $12.6^{\circ} \mathrm{C}$ (warming rate of $0.8^{\circ} \mathrm{Ch}^{-1}$ ). For the $35 \mathrm{~g} \mathrm{~kg}^{-1}$ salinity water (representing typical ocean salinity) the corresponding temperatures were $16.8^{\circ} \mathrm{C}$ at the start of the experiment, $0^{\circ} \mathrm{C}$ was the lowest temperature and $14.2^{\circ} \mathrm{C}$ at the end of the experiment. The corresponding cooling and warming rates were $1.4^{\circ} \mathrm{Ch}^{-1}$ and $1.1^{\circ} \mathrm{Ch}^{-1}$, respectively.

To examine the influence of various brackish water conditions on the particle number size distribution, experiments 
with differing salinities, but a relatively stable water temperature were conducted. Since the setup did not allow for maintaining cold temperatures and stirring the water to dissolve $\mathrm{NaCl}$ faster at the same time (stirring the water with the bucket in the tank was very cumbersome), it was decided to conduct the experiment with water at room temperature. After reaching a relatively stable water temperature the salinity was changed from clean MQ water to $35 \mathrm{~g} \mathrm{~kg}^{-1}$ water in 15 incremental steps by adding $\mathrm{NaCl}$.

In a final experiment the impact of an organic acid on the temperature dependent trend of particle number characteristics was examined. To achieve this water with a stable salinity of $35 \mathrm{~g} \mathrm{~kg}^{-1}$ was cooled down from $20.4^{\circ} \mathrm{C}$ to about $0^{\circ} \mathrm{C}$ (cooling rate of $1.5^{\circ} \mathrm{Ch}^{-1}$ ). While keeping the water temperature close to the freezing point, succinic acid (ACS reagent, $>99.0 \%$, Sigma-Aldrich) was stepwise added to the water in the tank, starting with a concentration of $94 \mu \mathrm{mol} \mathrm{L}^{-1}$ which is within the same order of magnitude of the estimated dissolved organic carbon concentration in Arctic Ocean waters (Kivimäe et al., 2010). After a succinic acid concentration of about $2450 \mu \mathrm{mol} \mathrm{L}^{-1}$ was reached, the water sample was left to warm up to a water temperature of about $13.3{ }^{\circ} \mathrm{C}$ (warming rate $1.1^{\circ} \mathrm{Ch}^{-1}$ ). It was chosen to conduct the cooling/warming experiment with the highest succinic acid concentration as this had proven to also have the largest effect on particle production. On average for all experiments, cooling water temperature down to the lowest temperature took $12 \mathrm{~h} 10$ min whereas the following warming up time was on average $14 \mathrm{~h} 20 \mathrm{~min}$.

Even though the focus of this paper is on the experiments conducted with $\mathrm{NaCl}$ solutions, data resulting from measurements with Arctic Ocean water are shown in addition. This is because the starting point for the presented study is the observations which were made with Arctic Ocean sea water. Experiments with Arctic Ocean sea water were conducted with a similar setup and instrumentation as described in Sects. 2.1 and 2.4. Water was sampled during late Arctic summer (from the 24th August to the 7th of September 2009) and late Arctic winter (from the 15th of February to the 7th of March 2010) from in total 4 different locations, in the vicinity of Kongsfjord/Svalbard. Characteristic of the different sampling location was the different influence with glacial melt water. Nevertheless presented data here include only waters with salinities between 34 and $35 \mathrm{~g} \mathrm{~kg}^{(-1)}$. The sampling during different seasons took place to account for both, biologically more active and less active waters.

\section{Data analysis}

To examine the influence of water temperature on particle number concentrations, data was organized into $1{ }^{\circ} \mathrm{C}$ water temperature bins. Median particle number concentrations were calculated for each temperature bin. Due to a fluctuating water level in the first two experiments, data were in- terpolated for the MQ and $18 \mathrm{~g} \mathrm{~kg}^{-1}$ saline water before the median was estimated.

Particle number size distributions of $\mathrm{NaCl}$ water with a salinity of $35 \mathrm{~g} \mathrm{~kg}^{-1}$ were averaged over four different water temperature ranges. The first range contained all size distributions resulting from waters having a temperature of $0{ }^{\circ} \mathrm{C}$ (total measurement time $1 \mathrm{~h} 25 \mathrm{~min}$ ), the second range included all size distributions between $1{ }^{\circ} \mathrm{C}$ and $4{ }^{\circ} \mathrm{C}$ (total measurement time $6 \mathrm{~h} 20 \mathrm{~min}$ ), the third contained all size distributions resulting from water with $T_{\mathrm{w}}$ between $8^{\circ} \mathrm{C}$ and $11^{\circ} \mathrm{C}$ (total measurement time $3 \mathrm{~h} 30 \mathrm{~min}$ ) and the last temperature range included waters with a temperature between $13^{\circ} \mathrm{C}$ and $16^{\circ} \mathrm{C}$ (total measurement time $1 \mathrm{~h} 50 \mathrm{~min}$ ). These temperature ranges were chosen to best represent the different steps of the experiment. The ranges $1{ }^{\circ} \mathrm{C}$ to $4^{\circ} \mathrm{C}$ and $8^{\circ} \mathrm{C}$ to $11^{\circ} \mathrm{C}$ were covered twice, first when the water was cooled down and second when the water was left to warm up again. The size distribution resulting from water with a $T_{\mathrm{w}}$ between $13^{\circ} \mathrm{C}$ and $16^{\circ} \mathrm{C}$ is only based on water which was cooled down, since no data were available for the warming part. While the range $1{ }^{\circ} \mathrm{C}$ to $4^{\circ} \mathrm{C}$ represents the lower part of the total temperature range, $8^{\circ} \mathrm{C}$ to $11^{\circ} \mathrm{C}$ represents the intermediate part and $13{ }^{\circ} \mathrm{C}$ to $16^{\circ} \mathrm{C}$ represents the upper part. The size distribution of $0^{\circ} \mathrm{C}$ water represents the turning point between cooling and warming of the water.

To examine the influence of salinity on the particle number size distribution, different salinities from $0 \mathrm{~g} \mathrm{~kg}^{-1} \mathrm{NaCl}$ to $35 \mathrm{~g} \mathrm{~kg}^{-1} \mathrm{NaCl}$ were binned into intervals of $3 \mathrm{~g} \mathrm{~kg}^{-1} \mathrm{NaCl}$, starting from $0 \mathrm{~g} \mathrm{~kg}^{-1} \mathrm{NaCl}$. For the resulting salinity bins the median $d N / d \log D_{\mathrm{p}}$ was calculated (based on at least five individual size distributions) to which lognormal functions were fitted. The fitting was made subjectively to bridge the overlapping region between the optical and electrical mobility size measurements around $D_{\mathrm{p}} 259 \mathrm{~nm}$. The fitted size distributions were normalized to their corresponding integral number to simplify comparison.

The median particle number size distributions resulting from $35 \mathrm{~g} \mathrm{~kg}^{-1} \mathrm{NaCl}$ water with different succinic acid concentrations $\left(0 \mu \mathrm{mol} \mathrm{L}-1,94 \mu \mathrm{mol} \mathrm{L}^{-1}\right.$, and $\left.565 \mu \mathrm{mol} \mathrm{L}-1\right)$ were compared to test the influence of different succinic acid concentrations in the water on particle number size distributions. Total measurement times of the size distributions were $50 \mathrm{~min}$ for $0 \mu \mathrm{mol} \mathrm{L}^{-1}$ water, $1 \mathrm{~h} 35 \mathrm{~min}$ for $94 \mu \mathrm{mol} \mathrm{L}^{-1}$ water, and $45 \mathrm{~min}$ for $565 \mu \mathrm{mol} \mathrm{L}{ }^{-1}$ water.

To explore the effect of possible additional organics and other inorganic salts than $\mathrm{NaCl}$ on particle number size distribution, median number size distributions of unadulterated Arctic water (total measurement time $25 \mathrm{~min}$ ), $\mathrm{NaCl}$ water with a succinic acid concentration of $2446 \mu \mathrm{mol} \mathrm{L}^{-1}$ (total measurement time $1 \mathrm{~h}$ ) and of $0 \mu \mathrm{mol} \mathrm{L}^{-1}$ (total measurement time $1 \mathrm{~h} 10 \mathrm{~min}$ ) were calculated. The water temperature for all waters was between $-0.5^{\circ} \mathrm{C}$ and $+0.5^{\circ} \mathrm{C}$ and salinity was kept between $35.0 \mathrm{~g} \mathrm{~kg}^{-1}$ and $35.6 \mathrm{~g} \mathrm{~kg}^{-1}$. For comparison, the number size distributions were normalized to their integral number based on the sum of four lognormal curve fits. 


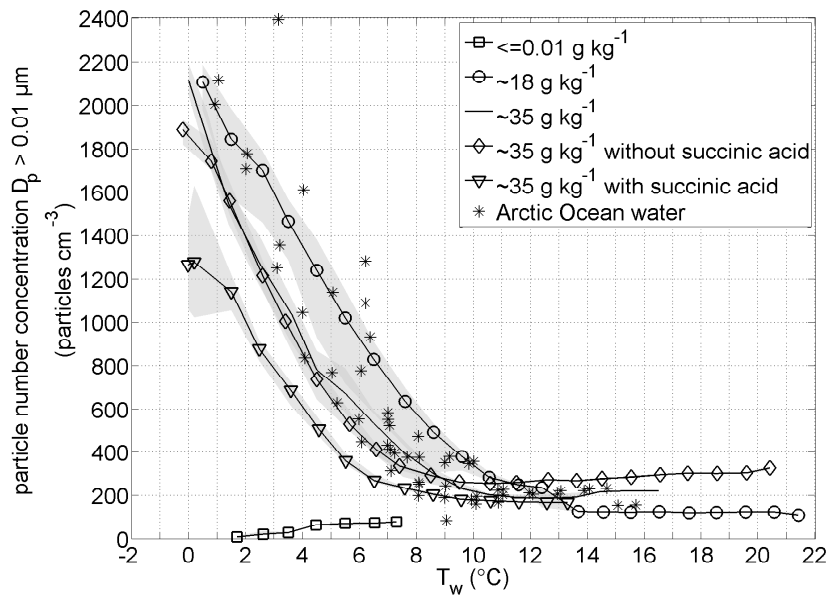

Fig. 2. Median particle number concentrations $\left(D_{\mathrm{p}}>0.01 \mu \mathrm{m}\right)$ for waters with different salinities and organic content as a function of water temperature $\left(T_{\mathrm{W}}\right)$. Grey shaded areas indicate the 25 th and 75th percentiles.

This fitting was conducted for the same reasons as described above. Parameters for the fitted size distributions are listed in Table 1. For the overlapping size range of DMPS and OPC measurements the first two size bins of the OPC measurements of $D_{\mathrm{p}} 265 \mathrm{~nm}$ and $D_{\mathrm{p}} 290 \mathrm{~nm}$ were not included for fitting the lognormal functions, but are included for completeness in the other number size distribution figures. Data points were omitted based on comparisons of total number concentration with the integral of the number size distribution including the first two size channels and rejecting the first two channels. Including the first two channels led to an underestimation of the total particle number. This decision was supported by evidence that for these sizes the DMPS measurements provide higher quality data; measurements with monodisperse polystyrene latex particles showed a steeply decreasing counting efficiency of the GRIMM 1.109 OPC below $15 \%$ for particles smaller than $D_{\mathrm{p}} 0.305 \mu \mathrm{m}$ (Heim et al., 2008).

\section{Results}

\subsection{MQ water experiments}

As a first step, an experiment with pure MQ water was performed to establish a basic test case for further experiments. Particle number concentration produced from MQ water increased slightly with increasing water temperature from $1.5^{\circ} \mathrm{C}$ to $7.5^{\circ} \mathrm{C}$ for particles with $D_{\mathrm{p}}>0.01 \mu \mathrm{m}$ (Fig. 2). The largest Poisson error of $4 \%$ was for the particle number concentration at $T_{\mathrm{w}}=1-2{ }^{\circ} \mathrm{C}$, corresponding to a deviation of about 0.5 particles $\mathrm{cm}^{-3}$ from the median concentration. Hence, the observed increasing trend is likely real. Nevertheless, the particle number concentration is relatively low $\left(80\right.$ particles $\mathrm{cm}^{-3}$ for water temperatures between $7^{\circ} \mathrm{C}$
Table 1. Parameters for fitted lognormal aerosol number size distributions with $\mathrm{Nx}$ as the number concentration $\left(\mathrm{cm}^{-3}\right), \operatorname{Dgx}$ as the geometric diameter $(\mu \mathrm{m})$ and $\sigma \mathrm{x}$ as the standard deviation for the different modes and waters: Arctic Ocean water (AO), $\mathrm{NaCl}$ water with a salinity of $35 \mathrm{~g} \mathrm{~kg}^{-1}$ and a succinic acid concentration of $0 \mu \mathrm{mol} \mathrm{L}{ }^{-1}(35 \mathrm{NaCl})$, and $\mathrm{NaCl}$ water with a salinity of $35 \mathrm{~g} \mathrm{~kg}^{-1}$ and a succinic acid concentration of $2446 \mu \mathrm{mol} \mathrm{L}^{-1}$ (35succ NaCl).

\begin{tabular}{lccc}
\hline & $\mathrm{AO}$ & $35 \mathrm{NaCl}$ & 35 succNaCl \\
\hline $\mathrm{N} 1$ & 430 & 880 & 465 \\
$\mathrm{Dg} 1$ & 0.073 & 0.07 & 0.07 \\
$\sigma 1$ & 2.3 & 2.08 & 2.1 \\
$\mathrm{~N} 2$ & 220 & 340 & 115 \\
$\mathrm{Dg} 2$ & 0.18 & 0.124 & 0.123 \\
$\sigma 2$ & 1.33 & 1.335 & 1.33 \\
$\mathrm{~N} 3$ & 245 & 565 & 307 \\
$\mathrm{Dg} 3$ & 0.48 & 0.225 & 0.226 \\
$\sigma 3$ & 1.48 & 1.20 & 1.17 \\
$\mathrm{~N} 4$ & 35 & 280 & 240 \\
$\mathrm{Dg} 4$ & 1.46 & 0.41 & 0.41 \\
$\sigma 4$ & 1.59 & 1.58 & 1.59 \\
\hline
\end{tabular}

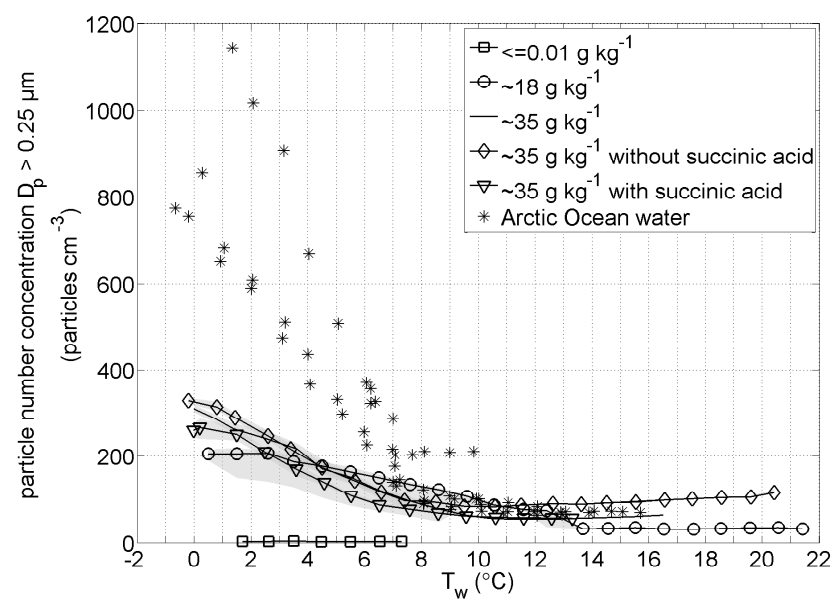

Fig. 3. Median particle number concentrations $\left(D_{\mathrm{p}}>0.25 \mu \mathrm{m}\right)$ for waters with different salinities and organic content as a function of water temperature $\left(T_{\mathrm{W}}\right)$. Grey shaded areas indicate the 25 th and 75 th percentiles.

and $8^{\circ} \mathrm{C}$ ) compared with waters of $18 \mathrm{~g} \mathrm{~kg}^{-1}$ and $35 \mathrm{~g} \mathrm{~kg}^{-1}$ salinity (at least 350 particles $\mathrm{cm}^{-3}$ for water temperatures between $7^{\circ} \mathrm{C}$ and $8^{\circ} \mathrm{C}$ ). For particles with $D_{\mathrm{p}}>0.25 \mu \mathrm{m}$ the particle number concentration is negligible (Fig. 3).

The MQ water test experiments set a baseline for the instrumental setup used. The increase of smaller particles with water temperature (cf. Fig. 2) likely results from an accumulation of dissolved impurities over time rather than from an increase in water temperature. This was tested by tilting the bottle in which the aerosols were produced allowing for water in the bottle to mix. Instantaneously the particle number concentration of particles with a $D_{\mathrm{p}}>0.01 \mu \mathrm{m}$ dropped down 
and increased slowly back to the previously concentration level (not shown here). This suggests that an accumulation of impurities on the water surface on which the water jet impinges, takes place. These substances might be either already present in the MQ water or are a consequence of flushing the system while conducting the experiments. Nevertheless the total number concentrations are negligible compared to the concentrations resulting from experiments with $18 \mathrm{~g} \mathrm{~kg}^{-1}$ and $35 \mathrm{~g} \mathrm{~kg}^{-1}$ saline water.

\subsection{Saline, "inorganic" water experiments}

The second experimental stage was the inclusion of $\mathrm{NaCl}$ to MQ water to produce the simplest possible sea water proxy. Here, sodium chloride was added in several consecutive steps increasing salinity to a typical oceanic level around $35 \mathrm{~g} \mathrm{~kg}^{-1}$. Similar to the previous test experiment with MQ water, changes in aerosol number concentration and size distribution were studied as function of $T_{\mathrm{w}}$ and also as a function of salinity. The particle number concentrations for waters with salinities of about $18 \mathrm{~g} \mathrm{~kg}^{-1}$ and $35 \mathrm{~g} \mathrm{~kg}^{-1}$ are shown as a function of water temperature (Figs. 2 and 3), and for comparison particle number concentrations resulting from Arctic Ocean water were added. The Arctic Ocean particle number concentrations are medians over each measured temperature bin and for every sampling location during the different seasons (late Arctic winter or late Arctic summer).

All median concentrations for particles with a $D_{\mathrm{p}}>0.01 \mu \mathrm{m}$ and a salinity of $18 \mathrm{~g} \mathrm{~kg}^{-1}$ and $35 \mathrm{~g} \mathrm{~kg}^{-1}$ show a clear trend of decreasing aerosol concentrations of about one order of magnitude with increasing water temperature from the lowest temperature bin to a water temperature of about $10^{\circ} \mathrm{C}$ (Fig. 2). For water temperatures above about $10^{\circ} \mathrm{C}$ (varying between $8{ }^{\circ} \mathrm{C}$ and $14^{\circ} \mathrm{C}$ depending on the experiment), the particle number concentration is rather stable. The particle production from the Arctic Ocean water has about the same temperature trend as the aerosols from the artificial waters. The absolut number concentrations cannot be compared directly due to different dilution factors of the aerosol sample with filtered air.

For particles with a $D_{\mathrm{p}}>0.25 \mu \mathrm{m}$ a decrease of particle number concentration from the lowest water temperature to $10^{\circ} \mathrm{C}$ is clearly visible for $35 \mathrm{~g} \mathrm{~kg}^{-1}$ saline water, while the trend starts for $18 \mathrm{~g} \mathrm{~kg}^{-1}$ saline water at $T_{\mathrm{w}}>2{ }^{\circ} \mathrm{C}$ (Fig. 3). The particle number concentration for $35 \mathrm{~g} \mathrm{~kg}^{-1}$ saline water is stable for $T_{\mathrm{w}}>10^{\circ} \mathrm{C}$ and for $18 \mathrm{~g} \mathrm{~kg}^{-1}$ saline water is stable for $T_{\mathrm{w}}>13.5^{\circ} \mathrm{C}$. The total particle number concentration for particles with a $D_{\mathrm{p}}>0.25 \mu \mathrm{m}$ decreased between three and four times from the lowest water temperatures around $0{ }^{\circ} \mathrm{C}$ to above $10-13^{\circ} \mathrm{C}$. The data resulting from Arctic Ocean water experiments exhibit the same trend for the particles $D_{\mathrm{p}}>0.25 \mu \mathrm{m}$ albeit with a steeper slope. The scattering of the particle number concentration resulting from Arctic Ocean water within the same water temperature range or in neighboring temperature bins is likely a result of

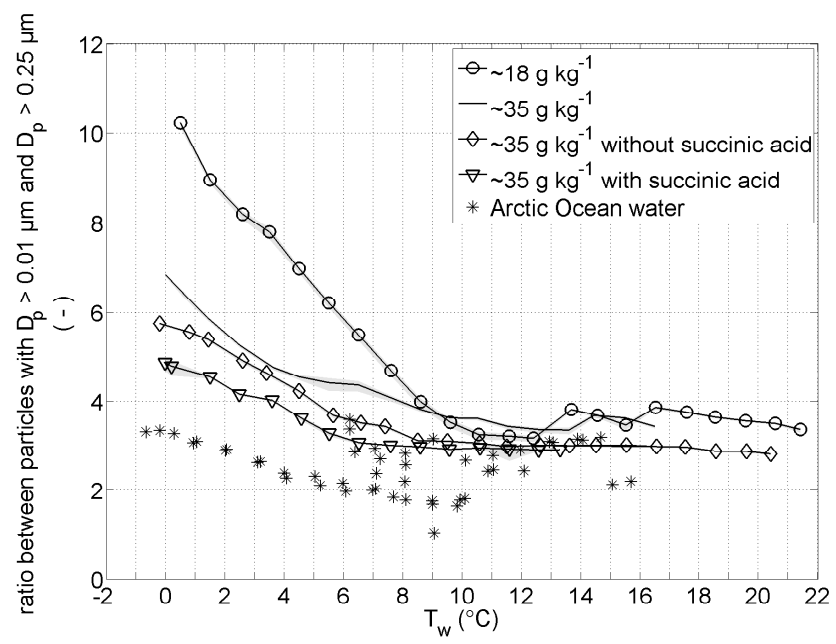

Fig. 4. Ratio between particles $D_{\mathrm{p}}>0.01 \mu \mathrm{m}$ and $D_{\mathrm{p}}>0.25 \mu \mathrm{m}$ for waters with different salinities and organic content as a function of water temperature $\left(T_{\mathrm{W}}\right)$. For comparison data from Arctic Ocean water is shown in addition. Grey shaded areas indicate the 25 th and 75th percentiles.

the natural variability as the samples were collected at different locations and at different times. However, the water temperature dependent trend is consistent for all waters.

The ratio of the particle number concentration of particles with $D_{\mathrm{p}}>0.01 \mu \mathrm{m}$ and $D_{\mathrm{p}}>0.25 \mu \mathrm{m}$ for the salinities $18 \mathrm{~g} \mathrm{~kg}^{-1}$ and $35 \mathrm{~g} \mathrm{~kg}^{-1}$ are presented in Fig. 4. There is a decrease from the lowest water temperature to a temperature of about $10^{\circ} \mathrm{C}$. For water temperatures larger than about $10^{\circ} \mathrm{C}$ no clear trend is observed. At low water temperatures close to $0^{\circ} \mathrm{C}, 85-90 \%$ of the sea spray aerosol population consists of particles $0.01 \mu \mathrm{m}<D_{\mathrm{p}}<0.25 \mu \mathrm{m}$ in case of artificial sea water with only $\mathrm{NaCl}$ added and about $75-80 \%$ for the Arctic Ocean water. At higher water temperatures the aerosol particles $0.01 \mu \mathrm{m}<D_{\mathrm{p}}<0.25 \mu \mathrm{m}$ represent between about $60-70 \%$ of aerosol population for both, artificial and real sea waters.

Overall, laboratory experiments using $\mathrm{MQ} \mathrm{NaCl}$ mixture show consistent number density dominated by sea spray aerosol by particles $0.01 \mu \mathrm{m}<D_{\mathrm{p}}<0.25 \mu \mathrm{m}$. This is also consistent with previous studies, e.g., on Atlantic Ocean sea water (Hultin et al., 2010) or in tropical Pacific Ocean (Clarke et al., 2006).

Comparing particle number size distributions of $35 \mathrm{~g} \mathrm{~kg}^{-1}$ $\mathrm{NaCl}$ water of the four water temperature ranges $0{ }^{\circ} \mathrm{C}, 1^{\circ} \mathrm{C}$ to $4{ }^{\circ} \mathrm{C}, 8^{\circ} \mathrm{C}$ to $11^{\circ} \mathrm{C}$, and $13{ }^{\circ} \mathrm{C}$ to $16^{\circ} \mathrm{C}$ show that the number size distribution resulting from the two lower temperature ranges have significant higher particle number concentrations than the size distributions based on the two higher temperature ranges for particle sizes $0.012 \mu \mathrm{m}<D_{\mathrm{p}}<1.5 \mu \mathrm{m}$ (see Fig. 5). All four distributions overlap for dry diameters outside this range. The two number size distributions resulting from higher water temperatures $\left(T_{\mathrm{w}}=8-11^{\circ} \mathrm{C}\right.$ and 
Table 2. Parameters for fitted lognormal aerosol number size distributions with $\mathrm{Nx}$ as the number concentration $\left(\mathrm{cm}^{-3}\right), \operatorname{Dgx}$ as the geometric diameter $(\mu \mathrm{m})$ and $\sigma \mathrm{x}$ as the standard deviation for the different modes and water temperatures $\left(T_{\mathrm{W}}\right): 0{ }^{\circ} \mathrm{C}, 1-4{ }^{\circ} \mathrm{C}, 8-$ $11^{\circ} \mathrm{C}$, and $13-16^{\circ} \mathrm{C}$.

\begin{tabular}{lcccc}
\hline $\mathrm{Tw}$ & $0{ }^{\circ} \mathrm{C}$ & $1-4{ }^{\circ} \mathrm{C}$ & $8-11^{\circ} \mathrm{C}$ & $13-16^{\circ} \mathrm{C}$ \\
\hline $\mathrm{N} 1$ & 380 & 220 & 60 & 45 \\
$\mathrm{Dg} 1$ & 0.037 & 0.035 & 0.03 & 0.028 \\
$\sigma 1$ & 1.6 & 1.6 & 1.8 & 1.8 \\
$\mathrm{~N} 2$ & 880 & 540 & 80 & 80 \\
$\mathrm{Dg} 2$ & 0.11 & 0.11 & 0.10 & 0.09 \\
$\sigma 2$ & 1.60 & 1.60 & 1.80 & 1.80 \\
$\mathrm{~N} 3$ & 770 & 450 & 60 & 50 \\
$\mathrm{Dg} 3$ & 0.235 & 0.235 & 0.250 & 0.250 \\
$\sigma 3$ & 1.25 & 1.25 & 1.25 & 1.25 \\
$\mathrm{~N} 4$ & 180 & 150 & 38 & 35 \\
$\mathrm{Dg} 4$ & 0.52 & 0.52 & 0.58 & 0.58 \\
$\sigma 4$ & 1.4 & 1.4 & 1.4 & 1.4 \\
$\mathrm{~N} 5$ & 16 & 18 & 10 & 10 \\
$\mathrm{Dg} 5$ & 1.45 & 1.55 & 1.7 & 1.8 \\
$\sigma 5$ & 1.4 & 1.4 & 1.4 & 1.4 \\
\hline
\end{tabular}

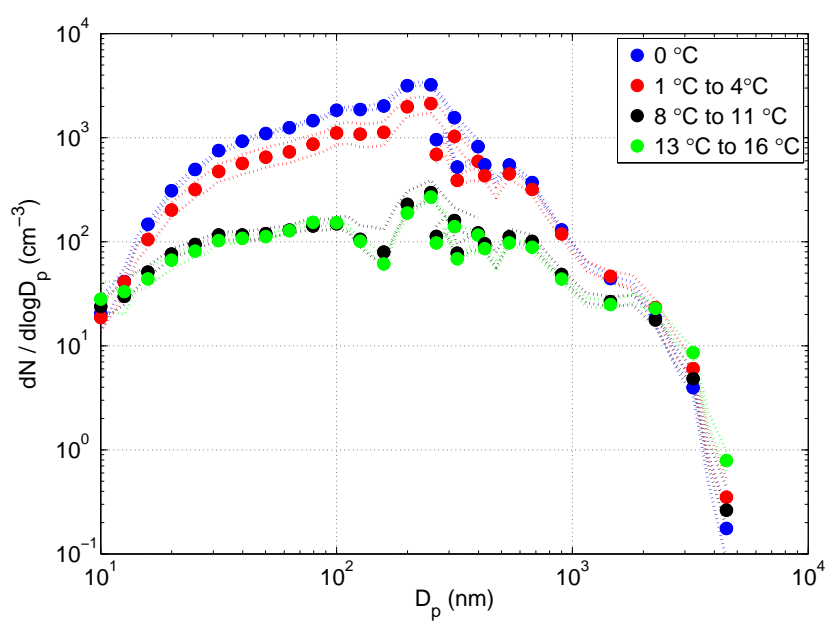

Fig. 5. Particle number size distributions from $35 \mathrm{~g} \mathrm{~kg}^{-1} \mathrm{NaCl}$ water for different water temperature ranges. Median size distributions were calculated for temperatures at $0{ }^{\circ} \mathrm{C}\left(\mathrm{RH}_{\text {mean }}=29 \%\right)$, between $1{ }^{\circ} \mathrm{C}$ and $4{ }^{\circ} \mathrm{C}\left(\mathrm{RH}_{\text {mean }}=29 \%\right)$, between $8{ }^{\circ} \mathrm{C}$ and $11^{\circ} \mathrm{C}\left(\mathrm{RH}_{\text {mean }}\right.$ $=30 \%)$ and between $13{ }^{\circ} \mathrm{C}$ and $16^{\circ} \mathrm{C}\left(\mathrm{RH}_{\text {mean }}=21 \%\right)$. Dotted lines represent the 25 th and 75 th percentiles. Only every second data point is shown for clarity.

$T_{\mathrm{w}}=13-16^{\circ} \mathrm{C}$ ) overlap over the whole size range. A local maximum between $D_{\mathrm{p}} 0.2 \mu \mathrm{m}$ and $0.25 \mu \mathrm{m}$ can be identified for all four size distributions. Log-normal fittings were performed for all four every size distribution and the resulting number size distribution parameters are listed in Table 2.

To demonstrate the influence of salinity on particle number size distributions for the salinity range $0-35 \mathrm{~g} \mathrm{~kg}^{-1}$, lognormally fitted size distributions normalized to the integral

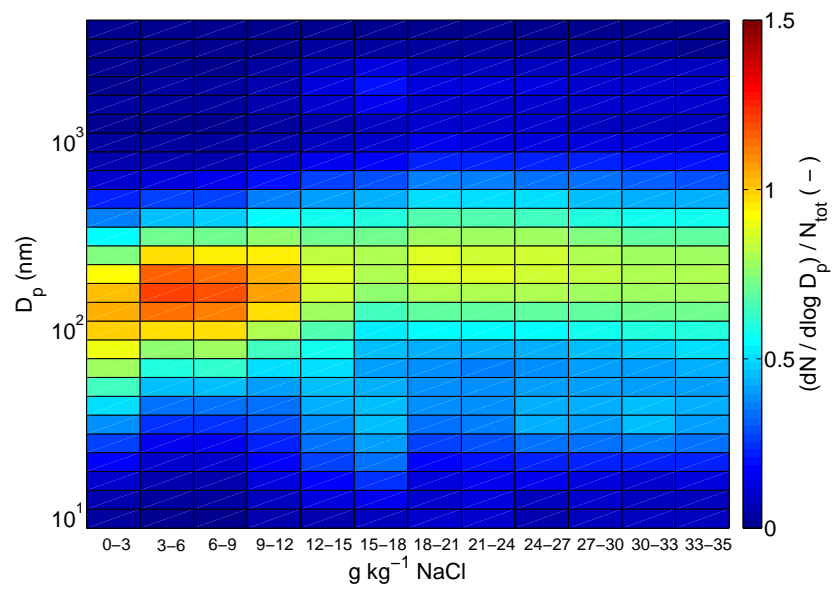

Fig. 6. Normalized fitted particle number size distributions for different salinity ranges. $\mathrm{RH}_{\text {mean }}=43 \%$ for salinities between 0 and $18 \mathrm{~g} \mathrm{~kg}^{-1} ; \mathrm{RH}_{\text {mean }}=24 \%$ for salinities between 18 and $35 \mathrm{~g} \mathrm{~kg}^{-1}$.

number density for the different salinity bins were compared (Fig. 6). Relative particle number concentrations for particles between $0.10 \mu \mathrm{m}<D_{\mathrm{p}}<0.23 \mu \mathrm{m}$ are higher for the lower salinities and decrease with increasing salinity until they remain stable at a salinity of about $15 \mathrm{~g} \mathrm{~kg}^{-1}$. As the relative humidity is rather high for the salinity range $0-18 \mathrm{~g} \mathrm{~kg}^{-1}$, it cannot be assumed that the particle diameters can be considered as dry diameters. Therefore, it might be that concentrations for real dry diameters are shifted towards smaller particle sizes. However, this would reveal the evolution observed in Fig. 6. The dominant mode seen in Fig. 6 also has a slight shift from about 0.142 to $0.225 \mu \mathrm{m} D_{\mathrm{p}}$ when the salinity increases from $0-3 \mathrm{~g} \mathrm{~kg}^{-1}$ to $12-15 \mathrm{~g} \mathrm{~kg}^{-1}$, above which the mode diameter is stable. Relative particle number concentrations for smaller and larger sizes differ as well for different salinities, but not in an identifiable direction. One exception is an indication of a weak tail of smaller particles from about $15 \mathrm{~g} \mathrm{~kg}^{-1}$. Generally, it can be said that there is a local maxima for all salinity bins at around $0.225 \mu \mathrm{m}$ and the number size distributions do not vary considerably in relative shape for salinities higher than $15 \mathrm{~g} \mathrm{~kg}^{-1}$. A comparison of particle number size distributions (not shown) resulting from waters having salinities between 30 and $35 \mathrm{~g} \mathrm{~kg}^{-1}$ (salinity bin size was $1 \mathrm{~g} \mathrm{~kg}^{-1}$ and the salinity range between 31 and $32 \mathrm{~g} \mathrm{~kg}^{-1}$ is not considered due to a small number of observations), did not show any systematic difference in number size distribution between the different salinity ranges. Parameters of lognormally fitted size distributions are listed in Table 3.

\subsection{Succinic acid experiment}

Succinic acid experiments were conducted to test the influence of different water temperatures on water containing a representative organic acid in addition to the $\mathrm{NaCl}$. Also, number size distributions resulting from $\mathrm{NaCl}$ waters with 
Table 3. Parameters for fitted lognormal aerosol number size distributions with $\mathrm{Nx}$ as the number concentration $\left(\mathrm{cm}^{-3}\right), \operatorname{Dgx}$ as the geometric diameter $(\mu \mathrm{m})$ and $\sigma \mathrm{x}$ as the standard deviation for the different modes and salinities: $30-31 \mathrm{~g} \mathrm{~kg}^{-1}, 32-33 \mathrm{~g} \mathrm{~kg}^{-1}, 33-$ $34 \mathrm{~g} \mathrm{~kg}^{-1}$, and $34-35 \mathrm{~g} \mathrm{~kg}^{-1}$.

\begin{tabular}{lcccc}
\hline salinity & $\begin{array}{c}30-31 \\
\mathrm{~g} \mathrm{~kg}^{-1}\end{array}$ & $\begin{array}{c}32-33 \\
\mathrm{~g} \mathrm{~kg}^{-1}\end{array}$ & $\begin{array}{c}33-34 \\
\mathrm{~g} \mathrm{~kg}^{-1}\end{array}$ & $\begin{array}{c}34-35 \\
\mathrm{~g} \mathrm{~kg}^{-1}\end{array}$ \\
\hline $\mathrm{N} 1$ & 50 & 55 & 60 & 50 \\
$\mathrm{Dg} 1$ & 0.030 & 0.033 & 0.033 & 0.030 \\
$\sigma 1$ & 1.55 & 1.60 & 1.60 & 1.60 \\
$\mathrm{~N} 2$ & 75 & 70 & 70 & 80 \\
$\mathrm{Dg} 2$ & 0.1 & 0.1 & 0.1 & 0.1 \\
$\sigma 2$ & 1.60 & 1.60 & 1.60 & 1.60 \\
$\mathrm{~N} 3$ & 45 & 45 & 45 & 45 \\
$\mathrm{Dg} 3$ & 0.24 & 0.24 & 0.25 & 0.25 \\
$\sigma 3$ & 1.20 & 1.20 & 1.20 & 1.20 \\
$\mathrm{~N} 4$ & 40 & 40 & 40 & 40 \\
$\mathrm{Dg} 4$ & 0.58 & 0.58 & 0.58 & 0.58 \\
$\sigma 4$ & 1.4 & 1.4 & 1.4 & 1.4 \\
$\mathrm{~N} 5$ & 11 & 11 & 11 & 11 \\
$\mathrm{Dg} 5$ & 1.9 & 1.9 & 1.9 & 1.9 \\
$\sigma 5$ & 1.4 & 1.4 & 1.4 & 1.4 \\
\hline
\end{tabular}

different succinic acid concentrations for a stable water temperature were compared to each other. Additionally, a size distribution of aerosols resulting from $\mathrm{NaCl}$ water was compared to a size distribution of aerosols resulting from $\mathrm{NaCl}$ water with added succinic acid and a size distribution of particles generated from Arctic Ocean water to demonstrate the combined influence of organics and other inorganic salts on the number size distribution.

Comparable to waters having a salinity of $18 \mathrm{~g} \mathrm{~kg}^{-1}$ and $35 \mathrm{~g} \mathrm{~kg}^{-1}$ without added succinic acid, the $35 \mathrm{~g} \mathrm{~kg}^{-1}$ saline water with a succinic acid concentration of $2446 \mu \mathrm{mol} \mathrm{L}^{-1}$ caused a similar decreasing trend in particle number concentration with increasing water temperature (Figs. 2 and 3). Nevertheless, the particle number concentration for $D_{\mathrm{p}}>0.01 \mu \mathrm{m}$ for water with succinic acid added is on an about $1 / 3$ lower level compared to the other saline waters. As the temperature approaches about $10^{\circ} \mathrm{C}$ the curves converge and the aerosol production from the succinic acid spiked water matches production during the inorganic experiments. For higher water temperatures the particle number concentrations level out. While an about tenfold decrease of particle number concentration was observed for the inorganic waters (for $D_{\mathrm{p}}>0.01 \mu \mathrm{m}$ ), the particle number concentration decreased only six times from the lowest temperature to above $10^{\circ} \mathrm{C}$ for the water spiked with succinic acid. For particles $D_{\mathrm{p}}>0.25 \mu \mathrm{m}$ there is no clear difference between inorganic experiments and experiments with succinic acid added to the water, see Fig. 3. The decreasing rates with increasing temperature are about three to four times and approximately similar for all saline experiments.

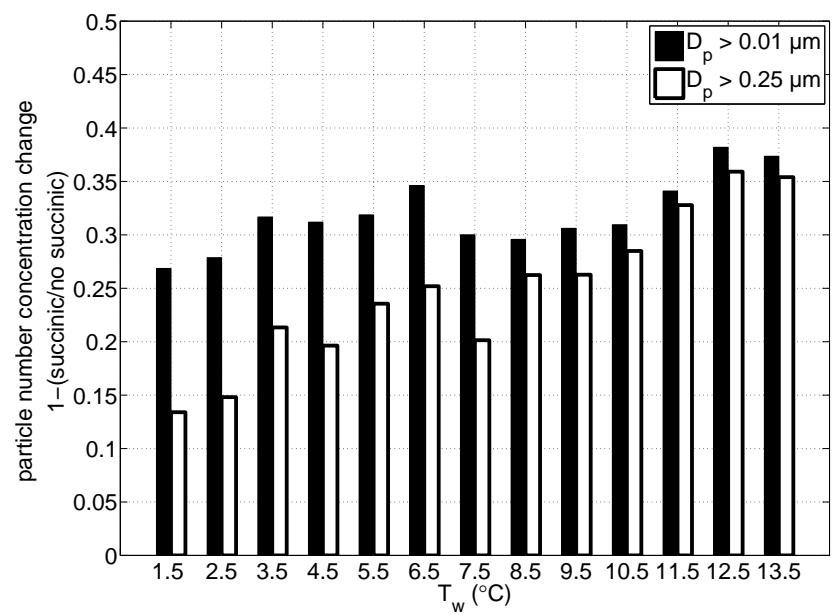

Fig. 7. Change of median particle number concentrations between particle number concentrations after adding succinic acid and before adding succinic acid as a function of water temperature $\left(T_{\mathrm{W}}\right)$.

A more detailed analysis shows that the change of particle number concentration between aerosols produced with and without adding succinic acid is not constant over the full temperature range (Fig. 7). For median temperatures between $1.5^{\circ} \mathrm{C}$ and $13.5^{\circ} \mathrm{C}$ the difference was always larger for the particles with $D_{\mathrm{p}}>0.01 \mu \mathrm{m}$ than for the particles with $D_{\mathrm{p}}>0.25 \mu \mathrm{m}$. While the change is increasing with increasing water temperature for particles with $D_{\mathrm{p}}>0.25 \mu \mathrm{m}$ (from about 15 to $35 \%$ ), a smaller increase is observed for the particles with a $D_{\mathrm{p}}>0.01 \mu \mathrm{m}$ (from about $27 \%$ to about $37 \%$ ).

As for all other saline waters, the ratio between $D_{\mathrm{p}}>0.01 \mu \mathrm{m}$ and $D_{\mathrm{p}}>0.25 \mu \mathrm{m}$ shows a decreasing trend with a corresponding water temperature increase from $0{ }^{\circ} \mathrm{C}$ to $7{ }^{\circ} \mathrm{C}$. At low $T_{\mathrm{w}}$ about $0^{\circ} \mathrm{C} 75-80 \%$ of all particles are within the size range $0.01 \mu \mathrm{m}<D_{\mathrm{p}}<0.25 \mu \mathrm{m}$ (Fig. 4).

Figure 8 shows particle number size distributions resulting from $\mathrm{NaCl}$ waters to which different amounts of succinic acid were added, resulting in succinic acid concentrations of $94 \mu \mathrm{mol} \mathrm{L}^{-1}$ and $565 \mu \mathrm{mol} \mathrm{L}^{-1}$. As a reference, a size distribution produced from pure $\mathrm{NaCl}$ water is shown in addition. All median water temperatures were in the range between -0.2 and $+0.2^{\circ} \mathrm{C}$ and medians of salinity were in the range between 35.4 and $35.5 \mathrm{~g} \mathrm{~kg}^{-1}$. The succinic acid concentration of $94 \mu \mathrm{mol} \mathrm{L}^{-1}$ is the same order of magnitude as the estimated dissolved organic carbon concentration in the Arctic Ocean (Kivimäe et al., 2010) and four orders of magnitude higher than the observed concentrations of succinic acid in the ocean (Tedetti et al., 2006). A change in succinic acid concentration from 0 to $94 \mu \mathrm{mol} \mathrm{L}-1$, resulted in an about $10 \%$ decrease for all examined sizes, whilst a succinic acid concentration change from 0 to $565 \mu \mathrm{mol} \mathrm{L}^{-1}$ resulted in an about $16 \%$ decrease. Log-normal fittings to the size distributions shown in Fig. 8 were performed. The resulting number size distribution parameters are presented in Table 4 . 


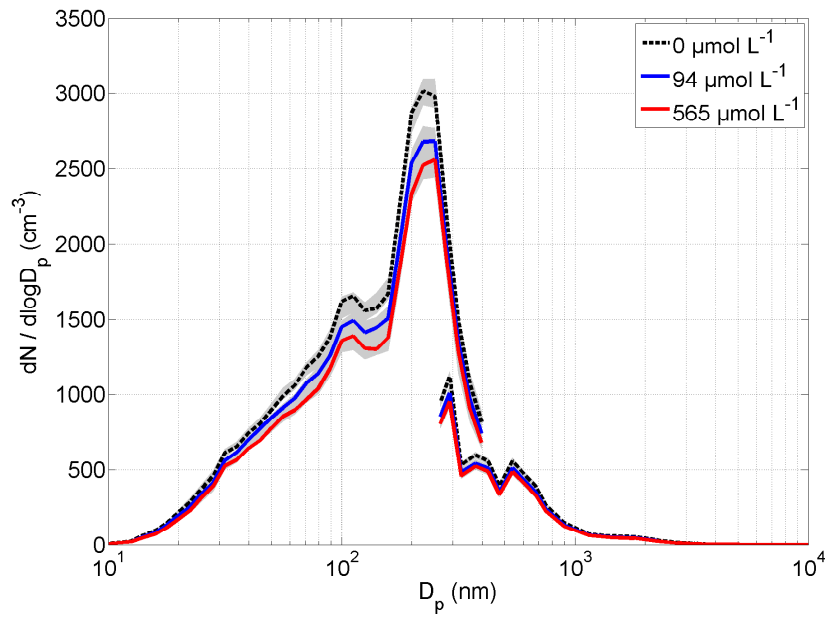

Fig. 8. Particle number size distributions for different succinic acid concentrations $\left(\mathrm{RH}_{\text {mean }}=23 \%\right)$. Water temperature medians are between 0.2 and $-0.2{ }^{\circ} \mathrm{C}$ and medians of salinity between 35.4 and $35.5 \mathrm{~g} \mathrm{~kg}^{-1}$. Measurement time per succinic acid concentration between about 40 and $90 \mathrm{~min}$. Grey shaded areas indicate the area between the 75 th and 25 th percentiles.

Table 4. Parameters for fitted lognormal aerosol number size distributions with $\mathrm{Nx}$ as the number concentration $\left(\mathrm{cm}^{-3}\right), \operatorname{Dgx}$ as the geometric diameter $(\mu \mathrm{m})$ and $\sigma \mathrm{x}$ as the standard deviation for the different modes and succinic acid concentrations in the water: $0 \mu \mathrm{mol} \mathrm{L}^{-1}, 94 \mu \mathrm{mol} \mathrm{L}^{-1}$, and $565 \mu \mathrm{mol} \mathrm{L}^{-1}$.

\begin{tabular}{lccc}
\hline $\begin{array}{l}\text { succinic acid } \\
\text { concentration }\end{array}$ & $0 \mu \mathrm{mol} \mathrm{L}$ & $94 \mu \mathrm{mol} \mathrm{L}^{-1}$ & $565 \mu \mathrm{mol} \mathrm{L}^{-1}$ \\
\hline $\mathrm{N} 1$ & 300 & 260 & 240 \\
$\mathrm{Dg} 1$ & 0.04 & 0.04 & 0.04 \\
$\sigma 1$ & 1.6 & 1.6 & 1.6 \\
$\mathrm{~N} 2$ & 740 & 680 & 620 \\
$\mathrm{Dg} 2$ & 0.105 & 0.105 & 0.105 \\
$\sigma 2$ & 1.6 & 1.6 & 1.6 \\
$\mathrm{~N} 3$ & 720 & 640 & 600 \\
$\mathrm{Dg} 3$ & 0.235 & 0.240 & 0.235 \\
$\sigma 3$ & 1.3 & 1.3 & 1.3 \\
$\mathrm{~N} 4$ & 170 & 160 & 150 \\
$\mathrm{Dg} 4$ & 0.530 & 0.530 & 0.530 \\
$\sigma 4$ & 1.4 & 1.4 & 1.4 \\
$\mathrm{~N} 5$ & 22 & 16 & 17 \\
$\mathrm{Dg} 5$ & 1.55 & 1.55 & 1.55 \\
$\sigma 5$ & 1.4 & 1.4 & 1.4 \\
\hline
\end{tabular}

Log-normally fitted and normalized number size distributions resulting from $35 \mathrm{~g} \mathrm{~kg}^{-1} \mathrm{NaCl}$ water, $35 \mathrm{~g} \mathrm{~kg}^{-1} \mathrm{NaCl}$ water with a succinic acid concentration of $2446 \mu \mathrm{mol} \mathrm{L}^{-1}$ and a normalized number size distribution resulting from Arctic Ocean water were compared to study the influence of different organic contents and salts other than $\mathrm{NaCl}$ on the particle number size distribution (Fig. 9). The Arctic Ocean water size distribution includes the contribution of unknown

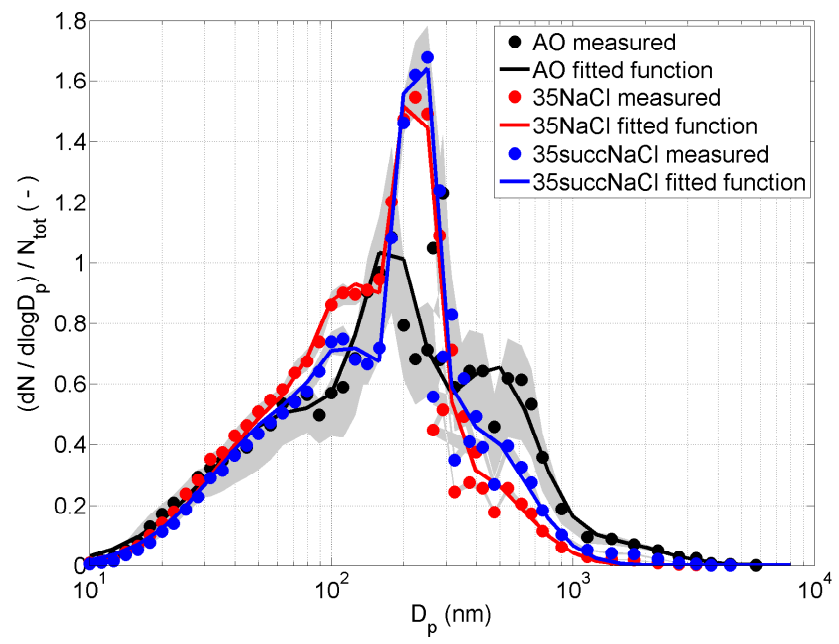

Fig. 9. Comparison between the normalized fitted particle number size distribution of Arctic Ocean water (water temperature median $-0.3{ }^{\circ} \mathrm{C}$, salinity median $35.0 \mathrm{~g} \mathrm{~kg}^{-1}, \mathrm{RH}_{\text {mean }}=7 \%$ ), sodium chloride water without succinic acid (water temperature median is $0.1^{\circ} \mathrm{C}$ and median salinity is $35.3 \mathrm{~g} \mathrm{~kg}^{-1}, \mathrm{RH}_{\text {mean }}=29 \%$ ) and sodium chloride water with succinic acid (water temperature median is $-0.1{ }^{\circ} \mathrm{C}$ and median salinity is $35.6 \mathrm{~g} \mathrm{~kg}^{-1}, \mathrm{RH}_{\text {mean }}=$ $23 \%$ ). The normalized size distributions measured and the 25 th and 75 th percentiles (grey shaded areas) are shown in addition.

organic substances and inorganic salts other than $\mathrm{NaCl}$, while the other size distributions are caused only by $\mathrm{NaCl}$ with or without succinic acid. Between particles with $D_{\mathrm{p}} 0.07$ to $0.14 \mu \mathrm{m}$ and particles with $D_{\mathrm{p}} 0.16$ to $0.3 \mu \mathrm{m}$ the synthetic water size distributions show relatively higher values than the Arctic Ocean size distribution with a distinct narrow peak close to $D_{\mathrm{p}} 0.25 \mu \mathrm{m}$. For particles $D_{\mathrm{p}}>0.316 \mu \mathrm{m}$ the normalized particle number concentration is higher for the ocean water up to a $D_{\mathrm{p}}$ of about $1.8 \mu \mathrm{m}$. For particle diameters larger than about $D_{\mathrm{p}} 1.8 \mu \mathrm{m}$ the normalized concentrations converge. The shapes of the normalized fitted size distributions of the two synthetic waters do not differ significantly, except for the magnitude between $D_{\mathrm{p}} 0.07 \mu \mathrm{m}$ and $0.16 \mu \mathrm{m}$ and between $D_{\mathrm{p}} 0.3 \mu \mathrm{m}$ and $1.0 \mu \mathrm{m}$ (Fig. 9). For the particles between $D_{\mathrm{p}} 0.07 \mu \mathrm{m}$ and $0.16 \mu \mathrm{m}$ the relative number is higher for the inorganic $\mathrm{NaCl}$ water than for the $\mathrm{NaCl}$ water with succinic acid. For the size range between $D_{\mathrm{p}} 0.3 \mu \mathrm{m}$ and $1.0 \mu \mathrm{m}$ it is reversed.

\section{Discussion and conclusion}

Warming/cooling experiments with a $\mathrm{NaCl}$ solution for water temperatures between 0 and $21^{\circ} \mathrm{C}$ confirmed the water temperature dependent trend of particle number concentration observed for Arctic Ocean water. It was shown, that this trend was clear and reproducible. This was tested by using a $\mathrm{NaCl}$ solution with a salinity of $35 \mathrm{~g} \mathrm{~kg}^{-1}$, an exaggerated low salinity of $18 \mathrm{~g} \mathrm{~kg}^{-1}$, and by using a $\mathrm{NaCl}$ 
solution with an exaggerated high succinic acid concentration of $2446 \mu \mathrm{mol} \mathrm{L}^{-1}$. Further experiments were conducted with a stable water temperature: It was shown that salinity concentrations between 15 and $35 \mathrm{~g} \mathrm{~kg}^{-1}$ did not impact on the relative shape of the size distribution; within the salinity range $30-35 \mathrm{~g} \mathrm{~kg}^{-1}$ no salinity dependent significant difference on the size dependent particle number concentration could be detected; examining different succinic acid concentrations in the water $\left(0 \mu \mathrm{mol} \mathrm{L}^{-1}, 94 \mu \mathrm{mol} \mathrm{L}^{-1}\right.$, and $565 \mu \mathrm{mol} \mathrm{L}^{-1}$ ) showed a decrease in particle number concentration with an increase in the succinic acid concentration.

When comparing particle number size distributions from different studies, it is important to consider that the mechanism used for generating the aerosols might alter the size distribution. Fuentes et al. (2010a) observed four aerosol modes at geometric diameters of $0.014 \mu \mathrm{m}, 0.048 \mu \mathrm{m}, 0.124 \mu \mathrm{m}$ and $0.334 \mu \mathrm{m}$ produced by a multiple plunging water jet system. From a higher significance of the fourth mode in the jet system compared to an atomizer, a glass filter and an aquarium diffuser as aerosol production mechanisms, it was concluded that the fourth mode is linked to a mechanism particularly occurring in the jet system. A water jet hitting the water surface can itself produce aerosols and is influencing the air bubbles that rise towards the water surface. Sellegri et al. (2006) also observed a higher significance of a mode $D_{\mathrm{p}} \geq 0.300 \mu \mathrm{m}$ for aerosols produced by a weir compared to aerosols produced by spargers. Most probably the particle number size distributions in the current study are also influenced by the aerosol production mechanism. However, since all size distributions were generated using a similar setup, a comparison between the different size distributions is reasonable. That said, comparison with other results presented in the literature has to be treated with caution due to different experimental setup and aerosol generation mechanisms, and different types of water and/or surfactants.

\subsection{Total particle number concentration, number size distribution, and water temperature}

All tested $\mathrm{NaCl}$ waters with salinities of $18 \mathrm{~g} \mathrm{~kg}^{-1}$ and $35 \mathrm{~g} \mathrm{~kg}^{-1}$ show a steep decrease of particle number concentration from temperatures of about $0{ }^{\circ} \mathrm{C}$ up to a temperature of about $8-14^{\circ} \mathrm{C}$. The ratio between particles with a $D_{\mathrm{p}}>0.01 \mu \mathrm{m}$ and particles with a $D_{\mathrm{p}}>0.25 \mu \mathrm{m}$ is decreasing with increasing $T_{\mathrm{w}}$. This is an effect due to a more pronounced decrease of particles with $D_{\mathrm{p}}>0.01 \mu \mathrm{m}$ compared to the decrease of particles with $D_{\mathrm{p}}>0.25 \mu \mathrm{m}$. The same patterns were observed during experiments with Arctic Ocean waters.

Further, it was demonstrated that the size distributions resulting from $35 \mathrm{~g} \mathrm{~kg}^{-1} \mathrm{NaCl}$ water, for different water temperature ranges, all show the same local maxima between $D_{\mathrm{p}}$ $0.20 \mu \mathrm{m}$ and 0.25 . For the sizes $0.012 \mu \mathrm{m}<D_{\mathrm{p}}<1.5 \mu \mathrm{m}$ the particle number size distributions resulting from the lower water temperature ranges $\left(0^{\circ} \mathrm{C}, 1^{\circ} \mathrm{C}\right.$ to $\left.4^{\circ} \mathrm{C}\right)$ show higher particle number concentrations than the size distribution generated from warmer water $\left(8^{\circ} \mathrm{C}\right.$ to $11^{\circ} \mathrm{C}$ and $13^{\circ} \mathrm{C}$ to $\left.16^{\circ} \mathrm{C}\right)$. Particle number concentrations resulting from the two highest water temperature ranges overlapped for the whole size spectrum. Zábori et al. (2012) used Arctic Ocean water and a setup similar to that presented in this paper for the experiments. Within the water temperature range between $-2{ }^{\circ} \mathrm{C}$ and $5^{\circ} \mathrm{C}$ it was observed that particle number concentrations for all sizes between $D_{\mathrm{p}} 0.012 \mu \mathrm{m}$ to about $D_{\mathrm{p}} 1.8 \mu \mathrm{m}$ exhibited higher particle number concentrations for lower water temperatures compared to higher water temperatures. For sizes larger than $D_{\mathrm{p}} 1.8 \mu \mathrm{m}$ the concentrations converge. Local maxima were found to be at $0.180 \mu \mathrm{m}$ and $0.57 \mu \mathrm{m}$. It was concluded that the shape of the size distribution is not influenced by the water temperature. Nevertheless, the relation between the observed local maxima varied slightly with water temperature. The experiments of Hultin et al. (2011) with ocean water from the Baltic Sea presented a significant decrease of particle number concentration for particles $0.02 \mu \mathrm{m}<D_{\mathrm{p}}<1.8 \mu \mathrm{m}$ from about 750 particles $\mathrm{cm}^{-3}$ at $4{ }^{\circ} \mathrm{C}$ to about 170 particles $\mathrm{cm}^{-3}$ at $14^{\circ} \mathrm{C}$. The aerosols were generated by a nearly identical setup to the one used in the current study. The studies are also comparable in that the temperature was gradually changed for the same water.

Bowyer et al. (1990) used a ROYCO Model 225/519 particle counter with six size channels from about $r>0.25$ to $r>5 \mu \mathrm{m}(80 \% \mathrm{RH}$ radius $(r))$. An increasing particle number production with increasing $T_{\mathrm{w}}$ (between $0^{\circ} \mathrm{C}$ and $30^{\circ} \mathrm{C}$ ) from the $r>1.5 \mu \mathrm{m}$ channel to the largest size channel was observed. The effect increased with size and for the largest channel $(r>5 \mu \mathrm{m})$ an increase of particle number of the factor 2-3 over the whole temperature range occurs. For the two smallest size channels (that is for particles $r<1.5 \mu \mathrm{m}$ ) and $T_{\mathrm{w}}$ below about $15^{\circ} \mathrm{C}$ the particle concentration decreased with increasing $T_{\mathrm{w}}$, up to a factor 4 . For temperatures higher than about $13^{\circ} \mathrm{C}$ the particle number concentration remained constant. The data Bowyer et al. (1990) used was from the same experiments as Monahan et al. (1982), using a $3 \mathrm{~m}$ long white cap simulation tank in which two waves of collected coastal water one on each side were produced and the bubble generation when the waves collided was used to emulate ocean conditions. Bowyer et al. (1990) tried several different regimes to change the water temperature. For most of their data the aerosol is counted and sized continuously as the water temperature changes with only small temperature increments between each reading, much like in the current study. With large increases in temperature between sets of two measurements, the particle production continued to decrease with an increase in $T_{\mathrm{w}}$ through the entire temperature range, well above $15^{\circ} \mathrm{C}$.

For particles $D_{\mathrm{p}}<0.1 \mu \mathrm{m}$, Mårtensson et al. (2003) observed increasing particle production with decreasing temperature using synthetic sea water (with constant water temperatures at $-2^{\circ} \mathrm{C}, 5^{\circ} \mathrm{C}, 15^{\circ} \mathrm{C}$ and $23^{\circ} \mathrm{C}$ ). The trend was the opposite for sizes above $D_{\mathrm{p}} 0.35 \mu \mathrm{m}$. Between $D_{\mathrm{p}} 0.1$ 
and $0.35 \mu \mathrm{m}$ there was no clear trend. In the experiments of Mårtensson et al. (2003) air bubbles were generated by pressing clean air through a glass frit, which was shown to be a less representative method to mimic sea spray formation (Fuentes et al., 2010a).

It can be concluded that the observed decrease of particle number concentration with increasing water temperature up to about $8-14{ }^{\circ} \mathrm{C}$ is likely independent of the mechanism with which the aerosols are produced, at least for small particles. Mårtensson et al. (2003) and Bowyer et al. (1990) agree that larger particles have the opposite temperature trend, but they disagree very much at which size the positive temperature trend begins. It is difficult to speculate on why Bowyer et al. (1990) and Mårtensson et al. (2003) observe this trend for the larger particles, given the huge differences in experimental setup and instrumentation.

Mårtensson et al. (2003) observed that between $T_{\mathrm{w}} 15^{\circ} \mathrm{C}$ and $23^{\circ} \mathrm{C}$ the production of the smallest particles decreased in line with the higher temperature ranges. In this it differs from the current study, with Hultin et al. (2011) and with most of the Bowyer et al. (1990) experiments. In Mårtensson et al. (2003) experiments, aerosol production was allowed to equilibrate at a constant water temperature, while $T_{\mathrm{w}}$ was changed continuously within our experiments and the study of Hultin et al. (2011). Interestingly, Bowyer et al. (1990) also observed a decrease of particle production with increasing $T_{\mathrm{w}}$ up to $30^{\circ} \mathrm{C}$, when considering experiments conducted over large temperature increments. Hence, it may be that the existence of a break in the temperature trend, and its exact location on the temperature scale, affects particle production.

Besides the setup, the observed trend of decreasing particle number concentration with increasing water temperature seems to be qualitatively independent of the three different water types. $\mathrm{NaCl}$ water (this study), artificial sea water (Mårtensson et al., 2003), and real ocean water (Bowyer et al., 1990) show a similar water temperature dependent trend. Therefore, it is more likely that the observed trend is driven by a physical change rather than by a chemical (or biological) change of the sea water, though details in the results may still depend on chemistry or experimental setup. This is supported by the reproducibility of the results when conducting the experiments with temperatures going from high water temperatures down to lower temperatures and up again to higher water temperatures.

Water temperature influences several physical properties involved in the shaping of the air bubble plume. Since sea spray is mainly produced by bursting bubbles, the water temperature is possibly important for the aerosol production. An increase in water temperature reduces viscosity of the water, decreases the solubility of gases and increases the molecular diffusivity. The lower viscosity of water results in higher rise speeds of the bubbles, influencing the gas exchange between the bubble and the water. A lower solubility of the gases increases the number of bubbles, but is compensated by an increase of the diffusivity (Thorpe et al., 1992). Also surface tension at the water and air interfaces (ocean-atmosphere as well as ocean-bubble air) is expected to change. A higher water temperature decreases the surface tension and therefore might alter the bubble spectra as well as the manner in which bubbles burst and droplets form. Thorpe et al. (1992) stated that the net effect of water temperature on bubble production is an exponential decrease of mean bubble concentrations with a halving for every $10^{\circ} \mathrm{C}$. Even if the net effect of water temperature on bubble concentration seems to be known, a net effect on the particle number production is not. However, the laboratory experiments together with measurements performed using real Arctic sea water and a comparison with the literature strongly point towards physically based temperature dependence of the bubble bursting process and sea spray formation. The chemical composition or the role of organic matter seems to play a less important role in these processes.

\subsection{Impact of organic content on particle number and number size distribution}

For testing the influence of organics on particle number concentration and number size distribution, experiments with $\mathrm{NaCl}$ waters having succinic acid concentrations from $94 \mu \mathrm{mol} \mathrm{L}^{-1}$ to up to $2446 \mu \mathrm{mol} \mathrm{L}^{-1}$ were conducted. Salinity was about $35.5 \mathrm{~g} \mathrm{~kg}^{-1}$ and water temperature about $0^{\circ} \mathrm{C}$. When the highest succinic acid concentration of $2446 \mu \mathrm{mol} \mathrm{L}^{-1}$ was reached, water temperature was left to warm up from $0{ }^{\circ} \mathrm{C}$ to about $13^{\circ} \mathrm{C}$. It was observed that higher succinic acid concentrations led to lower particle number concentrations for $D_{\mathrm{p}}<312 \mu \mathrm{m}$ at a water temperature of $0{ }^{\circ} \mathrm{C}$. The artificial $\mathrm{NaCl}$ water mixture with a succinic acid concentration of $2446 \mu \mathrm{mol} \mathrm{L}^{-1}$ resulted in a lower total particle number concentration over a wide temperature range (from about $0^{\circ} \mathrm{C}$ to $10-13^{\circ} \mathrm{C}$, depending on the salinity), especially for $0.01 \mu \mathrm{m}<D_{\mathrm{p}}<0.25 \mu \mathrm{m}$, compared to $\mathrm{NaCl}$ water mixtures to which no succinic acid was added. The difference in number concentration between water with and water without succinic acid for particles with $D_{\mathrm{p}}>0.25 \mu \mathrm{m}$ was smaller. For median water temperatures higher than $8.5^{\circ} \mathrm{C}$ the difference was less than $5 \%$.

A comparison between the log-normally fitted and normalized size distributions from the two synthetic waters showed that the aerosol number concentration resulting from pure $\mathrm{NaCl}$ water is relatively higher within $0.07 \mu \mathrm{m}$ to $0.16 \mu \mathrm{m}$ $D_{\mathrm{p}}$ than the number concentration of the size distribution resulting from the $\mathrm{NaCl}$ water plus succinic acid. For the size range $0.3 \mu \mathrm{m}<D_{\mathrm{p}}<1 \mu \mathrm{m}$ it is reversed. Between $0.316 \mu \mathrm{m}<D_{\mathrm{p}}<1.8 \mu \mathrm{m}$ the the Arctic Ocean water caused relatively higher number concentrations than the synthetic waters.

Sellegri et al. (2006) generated aerosols by a weir and compared normalized size distributions resulting from synthetic water (including $\mathrm{Cl}^{-}, \mathrm{Na}^{+}, \mathrm{SO}_{4}^{2-}, \mathrm{Mg}^{2+}, \mathrm{Ca}^{2+}$, and $\mathrm{K}^{+}$) and normalized size distributions resulting from 
synthetic water plus $5 \mathrm{mgL}^{-1}$ sodium dodecyl sulphate (SDS), which is probably the most commonly used detergent surfactant. For sizes about $0.06 \mu \mathrm{m}<D_{\mathrm{p}}<0.28 \mu \mathrm{m}$ the inorganic water caused higher relative number concentrations than the organic. The number concentration in the size distribution resulting from organic water exceeded that of the inorganic water for sizes from $0.28 \mu \mathrm{m}<D_{\mathrm{p}}<0.55 \mu \mathrm{m}$. These observations agree quite well with ours when comparing the size distributions derived from synthetic water to the size distributions produced by using Arctic Ocean water. For particle sizes lower than $D_{\mathrm{p}} 0.06 \mu \mathrm{m}$ Sellegri et al. (2006) reported that the size distribution derived from organic water was characterized by a higher particle number concentration than the one derived from inorganic water. This is not observed in our measurements. For all three waters the size distributions differ relatively little for sizes smaller than $D_{\mathrm{p}} 0.07 \mu \mathrm{m}$. Consequently, the influence of organics is negligible for the production of aerosols within these sizes, at least for our experimental setup and succinic acid. Sellegri et al. (2006) concluded that a size distribution shift to smaller sizes appeared to happen when adding SDS. Within our study, when adding succinic acid to the water or when using Arctic Ocean water, a shift to larger sizes was observed instead. Differences to the study of Sellegri et al. (2006) might be explained by the differences of the experimental setup, the difference of the synthetic water used including the difference in organic compound and concentration which was used. It appears that the results found when spiking synthetic water with one organic molecule cannot be extrapolated to other organic compounds. Although, it may seem that the effect of succinic acid qualitatively agrees better with what we found for the complex mixture of organics in the real ocean water (compared to the use of SDS by Sellegri et al., 2006), it has to be considered that the size distribution based on Arctic Ocean water is also likely influenced by the presence of other inorganic substances than $\mathrm{NaCl}$.

Tyree et al. (2007) used a diffuser to produce air bubbles in synthetic sea water $\left(\mathrm{Cl}^{-}, \mathrm{Na}^{+}, \mathrm{SO}_{4}^{2-}\right.$ and $\left.\mathrm{Mg}^{2+}\right)$ and compared resulting aerosol number size distributions to number size distributions resulting from artificial sea water plus 0.1 , 1 and $10 \mathrm{mg} \mathrm{L}^{-1}$ oleic acid. In contrast to succinic acid is oleic acid insoluble in water. Tyree et al. (2007) observed a uni-modal size distribution at around $D_{\mathrm{p}} 0.1 \mu \mathrm{m}$ for all experiments. Water with oleic acid resulted in higher total number concentrations compared to the synthetic water without any organic compound. The same was observed by Garrett (1968). A glass frit was used to produce air bubbles and the water was synthesized by adding $\mathrm{NaCl}$ until a salinity of $30 \%$ was reached. After adding oleic acid the particle number concentration increased. Garrett (1968) did not observe an increase of particles if the synthesized $\mathrm{NaCl}$ water was filtered twice before the experiment. It was concluded that foam stabilizing substances were present both in real sea water and in the $\mathrm{NaCl}$ water he synthesized. These substances delay the bubble bursting process. Adding oleic acid reduces the foam and thus the stability of the bubbles and result in higher particle production due to a higher bubble bursting rate.

Fuentes et al. (2010b) conducted experiments with a sea water proxy (artificial sea water enriched with diatomaceous bioexudates). For aerosol generation a multiple plunging water jet system was used. Compared to artificial (inorganic) seawater without any exudates the resulting number size distributions were shifted within the submicron size range to smaller sizes. This is qualitatively in agreement with Sellegri et al. (2006), but opposite to our results. An increase of particle number of particles with a $D_{\mathrm{p}}<0.1 \mu \mathrm{m}$ was observed for an increase of diatomaceous bio-exudates concentration between $175 \mu \mathrm{M} \mathrm{OC}<0.2 \mu \mathrm{m}$ and $300 \mu \mathrm{M} \mathrm{OC}<0.2 \mu \mathrm{m}$ (where $\mathrm{OC}<0.2 \mu \mathrm{m}$ stands for "organic carbon concentration" of water filtered through a filter with a pore size of $0.2 \mu \mathrm{m}$ ). This is also qualitatively in agreement with Sellegri et al. (2006) (the increase in number of particles below $0.06 \mu \mathrm{m}$ $D_{\mathrm{p}}$ when SDS was added), but not seen in our results. Even if the aerosol generation is similar in the current study, the organics added to the artificial seawater are quite different. Fuentes et al. (2010b) account not only for dissolved organic carbon, but also for colloidal organic matter attributed to the water insoluble part of primary marine aerosols. The insoluble organic carbon is not considered in our experiment when using $\mathrm{NaCl}$ water with succinic acid (since succinic acid is soluble), but probably is present in the Arctic Ocean water sample. Fuentes et al. (2010b) used the exudates of algae present in high biological active regions on the west coast of Africa, which is presumably different to the late winter Arctic Ocean water sample used in our experiments. Although different kind of surfactants used in the present study, the study by Sellegri et al. (2006), Tyree et al. (2007) and Fuentes et al. (2010b) makes it difficult to compare the results, it is important to mention that water temperature may have impacted as well on the surfactant's properties. While the presented succinic acid experiments were conducted with very low water temperatures around $0^{\circ} \mathrm{C}$, the other studies were conducted with waters having temperatures above $20^{\circ} \mathrm{C}$. It was shown that the critical micelle concentration in the water is a function of water temperature (Mehta et al., 2005; Chen et al., 1998). In addition it was demonstrated that already small changes of temperature can change the size, density, dielectrical proberties, and chemical reactivities of gels (Tanaka, 1992 in Verdugo et al., 2004).

If and how much the adding of succinic acid during our experiment might have influenced possible stabilizing substances present in the $\mathrm{NaCl}$ water is not clear. There are at least two mechanisms through which the succinic acid might influence the particle number production. On the one hand, it might stabilize or destabilize bubbles on the water surface due to reactions with other substances and on the other hand succinic acid might have influenced the bubble bursting through changes in the surface tension of the water and bubble surfaces. 


\subsection{Impact of salinity on particle number and size distributions}

Log-normally fitted and normalized size distributions were compared for different salinities from $0 \mathrm{~g} \mathrm{~kg}^{-1}$ up to $35 \mathrm{~g} \mathrm{~kg}^{-1}$ while the water temperature was stable. It was observed that relative particle number concentrations for particles between $0.10 \mu \mathrm{m}<D_{\mathrm{p}}<0.23 \mu \mathrm{m}$ are higher for the lower salinities and decrease with increasing salinity until they remain stable at a salinity of about $15 \mathrm{~g} \mathrm{~kg}^{-1}$ or higher. Scott (1975) examined the coalescence ability and air bubble stability on the water surface for different salinities $\left(0 \mathrm{~g} \mathrm{~L}^{-1}\right.$, $80 \mathrm{~g} \mathrm{~L}^{-1}$ and $350 \mathrm{~g} \mathrm{~L}^{-1}$ ). The coalescence of small air bubbles was more efficiently inhibited for higher salinities resulting in a lower rising velocity and therefore a delayed arrival to the water surface. Bubbles with a higher stability on the water surface were observed as a result of higher salinities. Blanchard $(1963,1988)$ stated that small bubbles produce rather jet drops and large bubbles rather film drops. If we assume that the $35 \mathrm{~g} \mathrm{~kg}^{-1}$ saline water produces more small bubbles which result in jet drop production, we would expect an increase of particles in the super micrometer aerosol range.

Mårtensson et al. (2003) compared number size distributions with salinities of $0 \mathrm{~g} \mathrm{~kg}^{-1}, 9.3 \mathrm{~g} \mathrm{~kg}^{-1}$ and $33 \mathrm{~g} \mathrm{~kg}^{-1}$. At higher salinity, higher number concentrations for particles with $D_{\mathrm{p}}>0.2 \mu \mathrm{m}$ but a conserved shape of the distribution was observed. Mårtensson et al. (2003) stated that the change was consistent with a total aerosol volume linearly proportional to the salinity. That would be the logical result if simply every droplet left a smaller dry aerosol particle due to lower salinity, but it would require the fresh sea spray size spectra to stay unchanged despite that the bubble spectra change.

Tyree et al. (2007), who used a diffuser and artificial water of different salinities (from 1 to $70 \%$ ), showed that the geometric mean diameter was almost constant with salinity, centered near $100 \mathrm{~nm}$ dry diameter, except for the lowest salinities where it changed towards slightly smaller sizes. This is in good agreement with our results. For the aerosol number concentration they found that it increased with increasing salinity, which cannot be confirmed from our measurements. Hultin et al. (2011) observed higher particle number concentrations over the whole measurement range for higher salinity ranges (examining real ocean water with salinities about $6 \mathrm{~g} \mathrm{~kg}^{-1}, 7 \mathrm{~g} \mathrm{~kg}^{-1}$ and $35 \mathrm{~g} \mathrm{~kg}^{-1}$ salinity), which is at least qualitatively in agreement with Tyree et al. (2007).

Russell and Singh (2006) experimented with three different sodium salts. They found that the aerosol mass was linear to the aqueous salt concentration, in agreement with Mårtensson et al. (2003). However, both number concentration and mean diameter depended on the one-sixth power of the aqueous concentration. This suggests that ionic forces retard the fluid motion and limit the bubble bursting process. They found that diameter, number and mass concentra- tions related to the non-dimensional fluid-mechanical Eötvös number (Eo), which indicates that the forces controlling the bubble bursting mechanism are described effectively by the ratio of buoyant and surface forces. Since they worked with $2 \mathrm{~mm}$ sized bubbles, their study concerns the few large bubbles and the film drops presumably produced from them. The large majority of bubbles in a full bubble spectrum (more representative of real ocean conditions) will be around $100 \mu \mathrm{m}$ diameter, and their Eo number will be far below the critical value found by Russell and Singh (2006).

The inorganic system with only salt and water may appear simple. Yet, when comparing studies in the literature and the current study, the results on how salinity influences the particle number size distribution differ considerably. These differences might arise from different combinations of salts in the waters used for the experiments, the presence of some organic compounds in the commercial aquarium salt mixtures used in some experiments, or the experimental setup. It can at least be concluded that the difference in salinity between $15 \mathrm{~g} \mathrm{~kg}^{-1}$ and $35 \mathrm{~g} \mathrm{~kg}^{-1} \mathrm{NaCl}$ concentration in our experiments have only little effect on the shape of the particle number size distribution, a conclusion supported by both Hultin et al. (2011) and Tyree et al. (2007).

\section{Future implications}

The effect on sea spray formation by changes in water temperature may have implications for the future climate in the Arctic. The decrease of particle number concentration with increasing water temperature might decrease the direct aerosol effect over the Arctic Ocean. On the one hand the decreased direct effect might result in a decrease of the negative radiative forcing at the top of the atmosphere, since less sea spray particles are emitted over the relatively dark sea surface. However, on the other hand a decreased direct effect may result in a decrease of the positive radiative forcing caused by a reduced sea spray concentration consisting of partly absorbing particles above a bright surface such as sea ice (Forster et al., 2007). At the same time the indirect effect of aerosols should decrease as well. Less small particles imply a reduction in cloud condensation nuclei and therefore might decrease cloud cover and with it lower albedo over the Arctic Ocean. This applies mainly to open Arctic waters, as Nilsson et al. (2001) showed that sea spray emissions within the central Arctic Ocean fields of sea ice are 1-2 orders of magnitude smaller than from open sea. During the last decades, Arctic Sea ice has retreated faster than climate models predict (Stroeve et al., 2007). Nilsson et al. (2001) was the first to suggest that in the Arctic, climate change would cause changes in sea spray emission due both to changes in local meteorology (e.g., higher wind speed) and the retreat of sea ice, which would also generate larger areas with higher sea spray emissions, a factor which may combine or compete with the ice albedo feed back. To this we 
can add the effects of changing water temperature. Recently, Struthers et al. (2011) used a GCM to quantify the increase in climate forcing caused by sea spray in a climate scenario with largely ice free summers in 2100 , and reported these to be between -0.2 and $-0.4 \mathrm{Wm}^{2}$; a negative feedback on the climate system. The model predicted that the change in the first indirect aerosol effect (cloud albedo effect) is approximately ten times greater than the change in direct aerosol forcing. Struthers et al. (2011) used the temperature dependency found by Mårtensson et al. (2003). However, numerous factors are expected to change in the Arctic regions and influence its climate (increased water vapor concentration and changing general circulation patterns etc.). The warming trend of the Arctic region is clear, but precise predictions are difficult. Nevertheless, implementing the boosted sea spray particle number emissions at low water temperatures into climate models may be important. A sensitivity test including also the effects of wind speed and sea ice on primary marine emissions might give valuable information about the relevance of the new water temperature dependence of particle number production and contribute to improving future climate predictions. As shown previously, a comparison between laboratory experiments is difficult due to different aerosol generation mechanisms, different waters, partly different water temperatures, and different organic substances used. More studies are needed for examining the influence of water temperature, salinity, soluble and insoluble organic substances present in different marine environments on particle number production by using only one experimental setup. Particular attention should be paid to the choice of the surfactant. A representative proxy for biogenic organic mixtures covering a wide range of molar masses and so a large variety in chemical and physical properties, should be chosen.

\section{Summary}

Earlier experiments conducted with Arctic Ocean water showed a dependence of primary marine particle number production on low water temperatures suggesting the development of a sea spray parameterization for high latitude oceans. Laboratory experiments with aerosol production by an impinging water jet on a water surface and subsequent bubble bursting were conducted to clarify the temperature dependence observed with ocean waters and potential influence of other parameters (salinity, organic content). Initially, experiments ran with pure $\mathrm{NaCl}$ water to exclude any influence on particle production by organic substances contained in the water. Later on succinic acid was added to the pure $\mathrm{NaCl}$ water to test the influence of a representative organic surfactant in the ocean. The total particle number concentration was examined as a function of water temperature (in the range from about $0^{\circ} \mathrm{C}$ up to $21^{\circ} \mathrm{C}$ ) for salinities of $0 \mathrm{~g} \mathrm{~kg}^{-1}, 18 \mathrm{~g} \mathrm{~kg}^{-1}$, and $35 \mathrm{~g} \mathrm{~kg}^{-1}$ and for water with a salinity of $35 \mathrm{~g} \mathrm{~kg}^{-1}$ and a succinic acid concentration of
$2446 \mu \mathrm{mol} \mathrm{L}{ }^{-1}$. Particle number size distributions resulting from $\mathrm{NaCl}$ water as a function of water temperature (examined $T_{\mathrm{w}}=0{ }^{\circ} \mathrm{C}, T_{\mathrm{w}}=1-4^{\circ} \mathrm{C}, T_{\mathrm{w}}=8-11^{\circ} \mathrm{C}$, and $T_{\mathrm{w}}=13-$ $16^{\circ} \mathrm{C}$ ) and as a function of succinic acid concentration $\left(0 \mu \mathrm{mol} \mathrm{L}^{-1}, 94 \mu \mathrm{mol} \mathrm{L}^{-1}\right.$, and $\left.565 \mu \mathrm{mol} \mathrm{L}^{-1}\right)$ were analysed. Additionally, normalized particle number concentrations for 12 different salinity ranges between 0 and $35 \mathrm{~g} \mathrm{~kg}^{-1}$ were compared to test the influence of salinity on relative particle number size distributions at a stable water temperature. The key findings of this study can be summed up to:

- Changes in water temperatures close to the freezing point strongly influence the total particle number concentration, especially for particles with $0.01 \mu \mathrm{m}<D_{\mathrm{p}}<0.25 \mu \mathrm{m}$. This is likely a consequence of physical rather chemical processes.

- Particle number concentrations resulting from $\mathrm{NaCl}$ water with a succinic acid concentration of $2446 \mu \mathrm{mol} \mathrm{L}^{-1}$ show the same water temperature dependent trend as pure $\mathrm{NaCl}$ waters, but on a lower particle concentration level.

- A water temperature change between $0{ }^{\circ} \mathrm{C}$ and $16^{\circ} \mathrm{C}$ does not change the shape of a particle number size distribution resulting from $\mathrm{NaCl}$ water $\left(35 \mathrm{~g} \mathrm{~kg}^{-1}\right.$ salinity).

- An increase of succinic acid concentration from $0 \mu \mathrm{mol} \mathrm{L}^{-1}$ to $94 \mu \mathrm{mol} \mathrm{L}^{-1}$ at a water temperature of $0{ }^{\circ} \mathrm{C}$ tends to decrease the particle number concentration for particles with $0.01 \mu \mathrm{m}<D_{\mathrm{p}}<4.5 \mu \mathrm{m}$ by about $10 \%$.

- High concentrations of succinic acid and other unknown organic components and inorganic salts present in Arctic Ocean water alter the size distribution resulting of pure $\mathrm{NaCl}$ water. A shift to larger sizes is observed from pure $\mathrm{NaCl}$ water to Arctic Ocean water.

- Salinity changes between $15 \mathrm{~g} \mathrm{~kg}^{-1}$ and $35 \mathrm{~g} \mathrm{~kg}^{-1}$ do not influence the shape of the particle number size distribution between $0.01 \mu \mathrm{m}<D_{\mathrm{p}}<5 \mu \mathrm{m}$ when using pure $\mathrm{NaCl}$ water.

Acknowledgements. Authors like to thank Michael Radke for providing laboratory equipment and Tabea Hennig, Kai Rosman and Monica Mårtensson for technical and field experiment support. Authors would like to thank also the Norwegian Polar Institute (NPI), Tromsø, Norway for logistical and field support and the Cryosphere-atmosphere interactions in a changing Arctic climate (CRAICC) initiative. Special acknowledgement belongs to personnel of the Sverdrup station at $\mathrm{Ny}$-Ålesund. This study was partly funded by Swedish Research Council (Vetenskaprådet): "The Green House Arctic Ocean and Climate Effects of Aerosols (GRACE), 2007-8362".

Edited by: G. McFiggans 


\section{References}

Blanchard, D. C.: The electrification of the atmosphere by particles from bubbles in the sea, Prog. Oceanogr., 1, 73-202, doi:10.1016/0079-6611(63)90004-1, 1963.

Blanchard, D. C. and Syzdek, L. D.: Film drop production as a function of bubble-size, J. Geophys. Res.-Ocean., 93, 3649-3654, doi:10.1029/JC093iC04p03649, 1988.

Bowyer, P. A., Woolf, D. K., and Monahan, E. C.: Temperature dependence of the charge and aerosol production associated with a breaking wave in a whitecap simulation tank, J. Geophys. Res.Ocean., 95, 5313-5319, doi:10.1029/JC095iC04p05313, 1990.

Chen, L.-C., Lin, S.-Y., Huang, C.-C. and Chen, E.-M.: Temperature dependence of critical micelle concentration of polyoxyethylenated non-ionic surfactants , Colloid Surface A, 135, 175-181, doi:10.1016/S0927-7757(97)00238-0, 1998.

Chin, W. C., Orellana, M. V., and Verdugo, P.: Spontaneous assembly of marine dissolved organic matter into polymer gels, Nature, 391, 568-572, doi:10.1038/35345, 1998.

Clarke, A. D., Owens, S. R., and Zhou, J.: An ultrafine sea-salt flux from breaking waves: Implications for cloud condensation nuclei in the remote marine atmosphere, J. Geophys. Res.-Atmos., 111, D06202, doi:10.1029/2005JD006565, 2006.

Comiso, J. C., Parkinson, C. L., Gersten, R., and Stock, L.: Accelerated decline in the Arctic sea ice cover, Geophys. Res. Lett., 35, L01703, doi:10.1029/2007GL031972, 2008.

Environmental Working Group (EWG): Oceanography atlas for the summer period, in Joint U.S.-Russian Atlas of the Arctic Ocean [CD-ROM], Univ. of Colo., Boulder, Colo., 1998.

Forster, P., Ramaswamy, V., Artaxo, P., Berntsen, T., Betts, R., Fahey, D. W., Haywood, J., Lean, J., Lowe, D. C., Myhre, G., Nganga, J., Prinn, R., Raga, G., Schulz, M., and Van Dorland, R.: Changes in Atmospheric Constituents and in Radiative Forcing. In: Climate Change 2007: The Physical Science Basis. Contribution of Working Group I to the Fourth Assessment Report of the Intergovernmental Panel on Climate Change, Cambridge University Press, Cambridge, UK and New York, NY, USA, 2007.

Fuentes, E., Coe, H., Green, D., de Leeuw, G., and McFiggans, G.: Laboratory-generated primary marine aerosol via bubblebursting and atomization, Atmos. Meas. Tech., 3, 141-162, doi:10.5194/amt-3-141-2010, 2010a.

Fuentes, E., Coe, H., Green, D., de Leeuw, G., and McFiggans, G.: On the impacts of phytoplankton-derived organic matter on the properties of the primary marine aerosol - Part 1: Source fluxes, Atmos. Chem. Phys., 10, 9295-9317, doi:10.5194/acp-10-92952010, 2010b.

Garrett, W. D.: Influence of monomolecular surface films on production of condensation nuclei from bubbled sea water, J. Geophys. Res., 73, 5145-5150, doi:10.1029/JB073i016p05145, 1968.

Giles, K. A., Laxon, S. W., Ridout, A. L., Wingham, D. J. and Bacon, S.: Western Arctic Ocean freshwater storage increased by wind-driven spin-up of the Beaufort Gyre, Nature Geosci., 5, 194-197, doi:10.1038/ngeo1379, 2012.

Gong, S. L.: A parameterization of sea-salt aerosol source function for sub- and super-micron particles, Global Biogeochem. Cy., 17, 1097, doi:10.1029/2003GB002079, 2003.

Grini, A., Myhre, G., Sundet, J. K., and Isaksen, I. S. A.: Modeling the annual cycle of sea salt in the global 3D model Oslo CTM2: Concentrations, fluxes, and radia- tive impact, J. Climate, 15, 1717-1730, doi:10.1175/15200442(2002)015<1717:MTACOS > 2.0.CO;2, 2002.

Haywood, J. M., Ramaswamy, V., and Soden, B. J.: Tropospheric aerosol climate forcing in clear-sky satellite observations over the oceans, Science, 283, 1299-1303, doi:10.1126/science.283.5406.1299, 1999.

Heim, M., Mullins, B. J., Umhauer, H., and Kasper, G.: Performance evaluation of three optical particle counters with an efficient "multimodal" calibration method, J. Aerosol Sci., 39, 1019-1031, doi:10.1016/j.jaerosci.2008.07.006, 2008.

Hultin, K. A. H., Nilsson, E. D., Krejci, R., Mårtensson, E. M., Ehn, M., Hagström, A., and de Leeuw, G.: In situ laboratory sea spray production during the Marine Aerosol Production 2006 cruise on the northeastern Atlantic Ocean, J. Geophys. Res.-Atmos., 115, doi:10.1029/2009JD012522, 2010.

Hultin, K. A. H., Krejci, R., Pinhassi, J., Gomez-Consarnau, L., Mårtensson, E. M., Hagström, Å., and Nilsson, E. D.: Aerosol and bacterial emissions from Baltic Seawater, Atmos. Res., 99, 1-14, doi:10.1016/j.atmosres.2010.08.018, 2011.

Hyvärinen, A. R., Lihavainen, H., Gaman, A., Vairila, L., Ojala, H., Kulmala, M., and Viisanen, Y.: Surface tensions and densities of oxalic, malonic, succinic, maleic, malic, and cis-pinonic acids, J. Chem. Eng. Data, 51, 255-260, doi:10.1021/je050366x, 2006.

Kester, A. S. and Foster, J. W.: Diterminal oxidation of long-chain alkanes by bacteria, J. Bacteriol., 85, 859-869, 1963.

Kivimäe, C., Bellerby, R. G. J., Fransson, A., Reigstad, M., and Johannessen, T.: A carbon budget for the Barents Sea, Deep-Sea Res. I - Oceanogr. Res. Pap., 57, 1532-1542, doi:10.1016/j.dsr.2010.05.006, 2010.

Ma, X., von Salzen, K., and Li, J.: Modelling sea salt aerosol and its direct and indirect effects on climate, Atmos. Chem. Phys., 8, 1311-1327, doi:10.5194/acp-8-1311-2008, 2008.

MacDonald, R. W., McLaughlin, F. A., and Carmarck, E. C.: Fresh water and its sources during the SHEBA drift in the Canada basin of the Arctic Ocean, Deep-Sea Res. I, 49, 1769-1785, doi:10.1016/S0967-0637(02)00097-3, 2002.

Mahiuddin, S., Minofar, B., Borah, J. M., Das, M. R., and Jungwirth, P.: Propensities of oxalic, citric, succinic, and maleic acids for the aqueous solution/vapour interface: Surface tension measurements and molecular dynamics simulations, Chem. Phys. Lett., 462, 217-221, doi:10.1016/j.cplett.2008.07.085, 2008.

Mårtensson, E. M., Nilsson, E. D., de Leeuw, G., Cohen, L. H., and Hansson, H.-C.: Laboratory simulations and parameterization of the primary marine aerosol production, J. Geophys. Res.-Atmos., 108, 4297, doi:10.1029/2002JD002263, 2003.

Mehta, S. K., Bhasin, K. K., Chauhan, R., and Dham, S.: Effect of temperature on critical micelle concentration and thermodynamic behavior of dodecyldimethylethylammonium bromide and dodecyltrimethylammonium chloride in aqueous media, Colloid Surface A, 255, 153-157, doi:10.1016/j.colsurfa.2004.12.038, 2005.

Monahan, E. C., Davidson, K. L., and Spiel, D. E.: Whitecap Aerosol Productivity Deduced from Simulation Tank Measurements, J. Geophys. Res.-Ocean. Atmos., 87, 8898-8904, doi:10.1029/JC087iC11p08898, 1982.

Monahan, E. C., Spiel, D. E., and Davidson, K. L.: A model of marine aerosol generation via whitecaps and wave disruption. In: Oceanic Whitecaps and Their Role in Air-Sea Exchange Processes, D. Reidel Publishing Company, 167-174, 1986. 
Nilsson, E. D., Rannik, U., Swietlicki, E., Leck, C., Aalto, P. P., Zhou, J., and Norman, M.: Turbulent aerosol fluxes over the Arctic Ocean 2. Wind-driven sources from the sea, J. Geophys. Res.Atmos., 106, 32139-32154, doi:10.1029/2000JD900747, 2001.

Nuth, C., Moholdt, G., Kohler, J., Hagen, J. O., and Kääb, A.: Svalbard glacier elevation changes and contribution to sea level rise, J. Geophys. Res.-Earth Surf., 115, doi:10.1029/2008JF001223, 2010.

Passow, U.: Transparent exopolymer particles (TEP) in aquatic environments, Prog. Oceanogr., 55, 287-333, doi:10.1016/S00796611(02)00138-6, 2002.

Pierce, J. R. and Adams, P. J.: Global evaluation of CCN formation by direct emission of sea salt and growth of ultrafine sea salt, J. Geophys. Res.-Atmos., 111, doi:10.1029/2005JD006186, 2006.

Raskoff, K. A., Hopcroft, R. R., Kosobokova, K. N., Purcell, J. E., and Youngbluth, M.: Jellies under ice: ROV observations from the Arctic 2005 hidden ocean expedition, Deep-Sea Res. II, 57, 111-126, doi:10.1016/j.dsr2.2009.08.010, 2010.

Russell, L. M. and Singh, E. G.: Submicron salt particle production in bubble bursting, Aerosol Sci. Technol., 40, 664-671, doi:10.1080/02786820600793951, 2006.

Scott, J. C.: The role of salt in whitecap persistence, Deep-Sea Research, 22, 653-657, 1975.

Sellegri, K., O’Dowd, C. D., Yoon, Y. J., Jennings, S. G., and de Leeuw, G.: Surfactants and submicron sea spray generation, J. Geophys. Res.-Atmos., 111, doi:10.1029/2005JD006658, 2006.

Steele, M., Ermold, W., and Zhang, J.: Arctic Ocean surface warming trends over the past 100 years, Geophys. Res. Lett., 35, L02614, doi:10.1029/2007GL031651, 2008.

Steinberg, S. M. and Bada, J. L.: Oxalic, Glyoxalic and Pyruvic acids in eastern Pacific-Ocean waters, J. Marine Res., 42, 697708, 1984.

Stepanova, A., Taldenkova, E., Simstich, J., and Bauch, H. A.: Comparison study of the modern ostracod associations in the Kara and Laptev seas: Ecological aspects, Mar. Micropaleontol., 63, 111-142, doi:10.1016/j.marmicro.2006.10.003, 2007.

Stroeve, J., Holland, M. M., Meier, W., Scambos, T., and Serreze, M.: Arctic sea ice decline: Faster than forecast, Geophys. Res. Lett., 34, L09501, doi:10.1029/2007GL029703, 2007.

Struthers, H., Ekman, A. M. L., Glantz, P., Iversen, T., Kirkevåg, A., Mårtensson, E. M., Seland, Ø., and Nilsson, E. D.: The effect of sea ice loss on sea salt aerosol concentrations and the radiative balance in the Arctic, Atmos. Chem. Phys., 11, 3459-3477, doi:10.5194/acp-11-3459-2011, 2011.

Tanaka, T.: Phase transition of gels, A.C.S. Symp. Ser., 480, 1-21, doi:10.1021/bk-1992-0480.ch001, 1992.
Tedetti, M., Kawamura, K., Charriere, B., Chevalier, N., and Sempere, R.: Determination of low molecular weight dicarboxylic and ketocarboxylic acids in seawater samples, Analyt. Chem., 78, 6012-6018, doi:10.1021/ac052226w, 2006.

Textor, C., Schulz, M., Guibert, S., Kinne, S., Balkanski, Y., Bauer, S., Berntsen, T., Berglen, T., Boucher, O., Chin, M., Dentener, F., Diehl, T., Easter, R., Feichter, H., Fillmore, D., Ghan, S., Ginoux, P., Gong, S., Grini, A., Hendricks, J., Horowitz, L., Huang, P., Isaksen, I., Iversen, I., Kloster, S., Koch, D., Kirkevåg, A., Kristjansson, J. E., Krol, M., Lauer, A., Lamarque, J. F., Liu, X., Montanaro, V., Myhre, G., Penner, J., Pitari, G., Reddy, S., Seland, Ø., Stier, P., Takemura, T., and Tie, X.: Analysis and quantification of the diversities of aerosol life cycles within AeroCom, Atmos. Chem. Phys., 6, 1777-1813, doi:10.5194/acp-6-1777-2006, 2006.

Thorpe, S. A., Bowyer, P., and Woolf, D. K.: Some factors affecting the size distributions of oceanic bubbles, J. Phys. Oceanogr., 22, 382-389, doi:10.1175/15200485(1992)022;0382:SFATSD ¿2.0.CO;2, 1992.

Tremblay, J.-E., Bélanger, S., Barber, D. G., Asplin, M., Martin, J., Darnis, G., Fortier, L., Gratton, Y., Link, H., Archambault, P., Sallon, A., Michel, C., Williams, W. J., Philippe, B., and Gosselin, M.: Climate forcing multiplies biological productivity in the coastal Arctic Ocean, Geophys. Res. Lett., 38, L18604, doi:10.1029/2011GL048825, 2011.

Tyree, C. A., Hellion, V. M., Alexandrova, O. A., and Allen, J. O.: Foam droplets generated from natural and artificial seawaters, J. Geophys. Res.-Atmos., 112, D12204, doi:10.1029/2006JD007729, 2007.

Verdugo, P., Alldredge, A. L., Azam, F., Kirchman, D. L., Passow, U., and Santschi, P. H.: The oceanic gel phase: a bridge in the DOM-POM continuum, Mar. Chem., 92, 67-85, doi:10.1029/2002GL016046, 2004.

Wassmann, P. and Reigstad, M.: Future Arctic Ocean seasonal ice zones and implications for pelagic-benthic coupling, Oceanography, 24, 220-231, 2011.

Zábori, J., Krejci, R., Ekman, A. M. L., Mårtensson, E. M., Ström, J., de Leeuw, G., and Nilsson, E. D.: Wintertime Arctic Ocean sea water properties and primary marine aerosol concentrations, Atmos. Chem. Phys., 12, 10405-10421, doi:10.5194/acp-1210405-2012, 2012.

Zhao, T. X. P., Yu, H., Laszlo, I., Chin, M., and Conant, W. C.: Derivation of component aerosol direct radiative forcing at the top of atmosphere for clear-sky oceans, J. Quant. Spectrosc. Radiat. Transf., 109, 1162-1186, doi:10.1016/j.jqsrt.2007.10.006, 2008. 